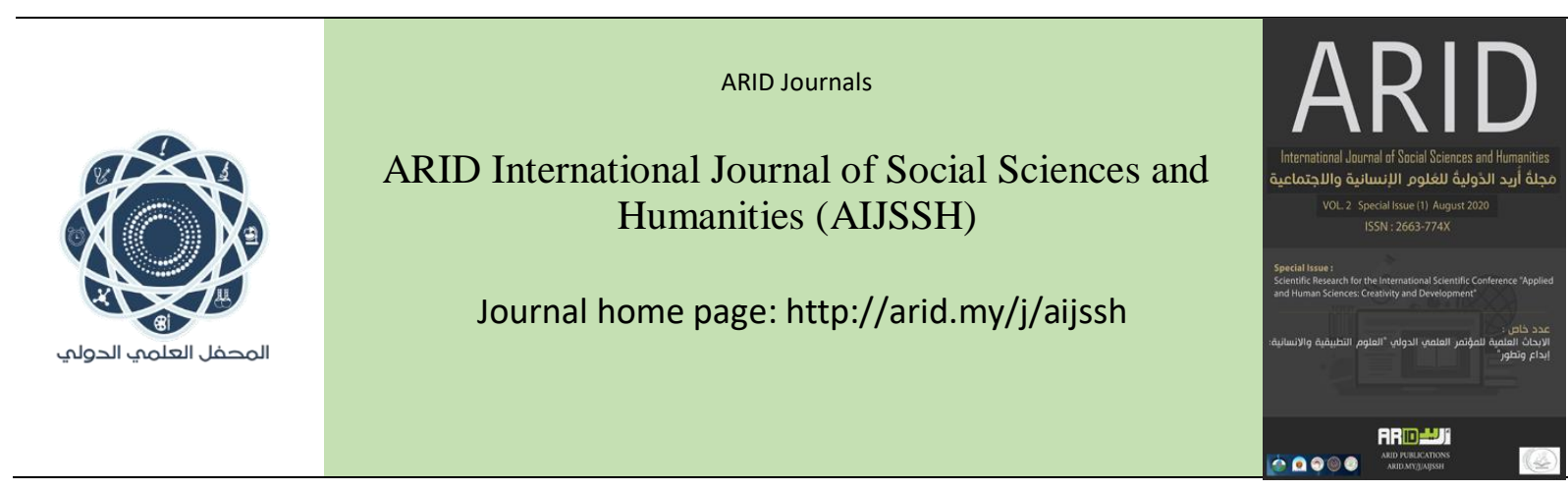

\title{
Homosexuality Between Religious prohibition and Legal approval (comparative study)
}

\section{ظاهرة المثلية بين التجريم الثرعي والإباحة القانونية (در اسة مقارنة الثمئ)}

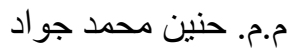

م.د. سارة صباح الهنداوي

م.د. ملاك عبد اللطيف التميمي*

كلية الصفوة الجامعةــ كربلاء/ العراق

كلية الحقوق-جامعة النهرين- بغداد- العراق

كلية الصفوة الجامعة_كربلاءـ العراق
}

Nirvanabloom2@gmail.com

Arid.my/0004-7432

https://doi.org/10.36772/arid.aijssh.2020.s.2124 


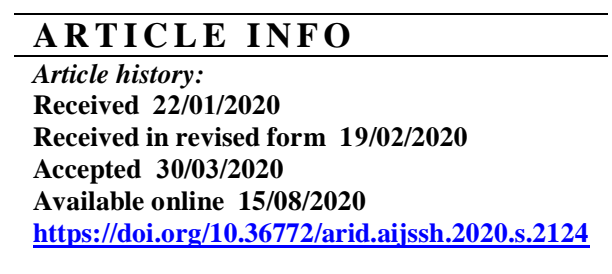

\begin{abstract}
The topic of homosexuality in addition to being one of the topics in which research studies are rare is one of the sensitive and recent important topics that must be alerted to its spread due to its seriousness that beats our standards today in our Arab world after entering technology in its broadest doors with weak media dominance over the media system and technological means of communication in addition to Sagging infrastructures concerned with educating the individual, especially the young man, and his insight into the importance of the teachings of his religion. Specialized statistics diagnosed the spread of this phenomenon in the Arab world, And their defiance of laws and laws that prohibit and criminalize this act, with the emergence of legal legislation in foreign countries that allow gay marriage and lift penalties for them and see these practices as legitimate exercise of freedom because the reasons for the deviation of their tendencies are biological, as they say, and therefore we will discuss this phenomenon through its concept by definition Historical basis, We will also discuss forensic criminalization by stating the religiously forbidden religious refusal of these relations, comparing this position with some legislation attempting to include it within the accepted legislative system, while we find other legislation that has not known the phenomenon nor criminalized by Iraqi punitive legislation, as we have tried to find this phenomenon an appropriate legal adaptation but we have not succeeded in Finding an adequate legal basis for this crime, so it would have been better if such texts were legislated, by adopting the comparative approach in the study.
\end{abstract}




\section{الملخص}

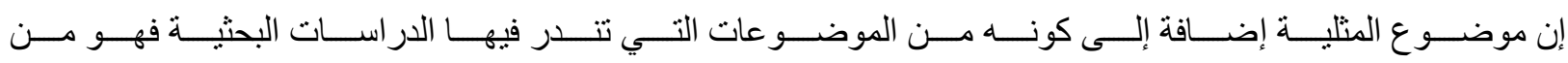

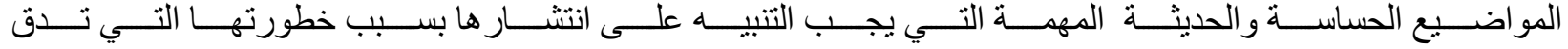

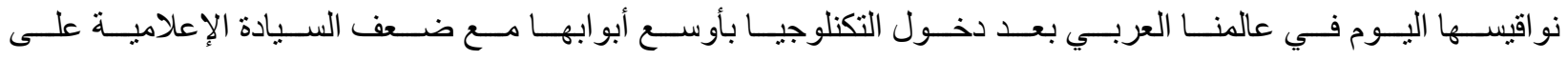

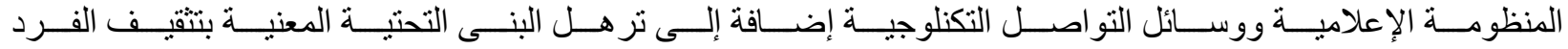

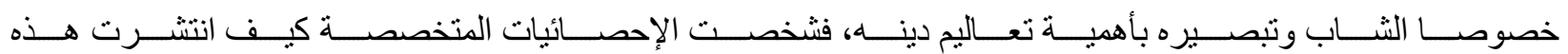

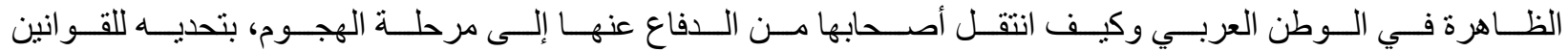

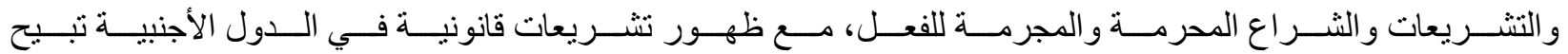

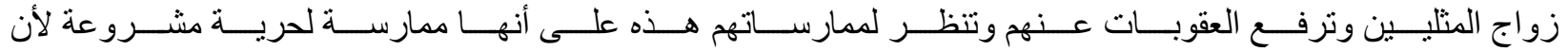

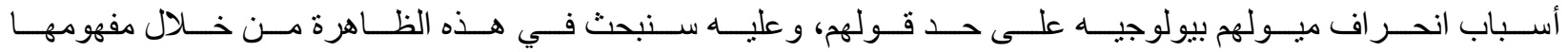

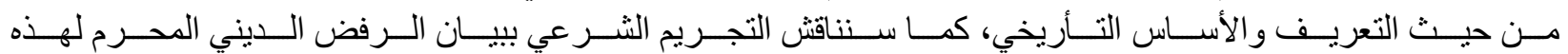

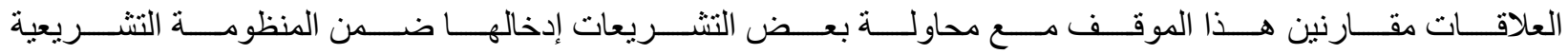

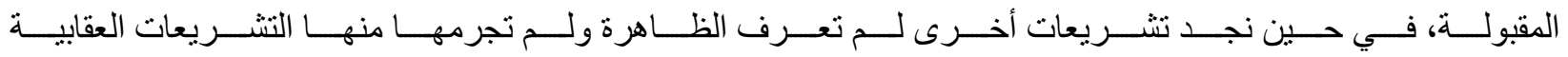

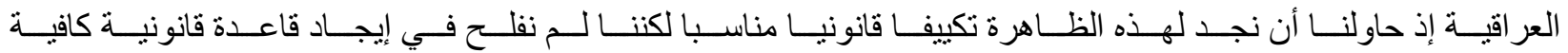

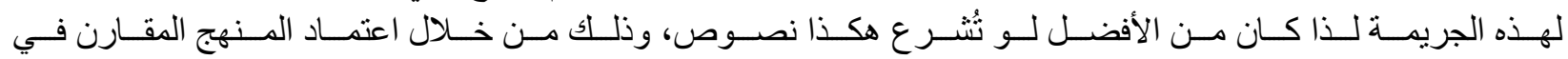
الدر اسة.

\section{الكلمات المفتاحية}

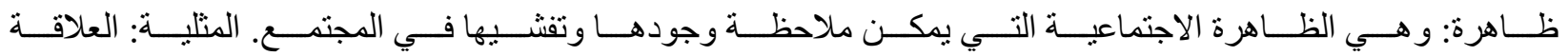

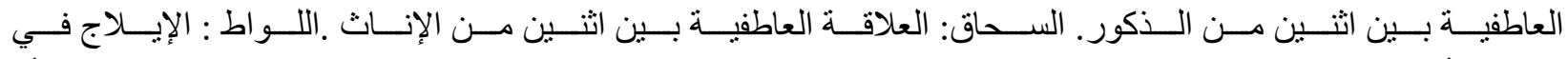

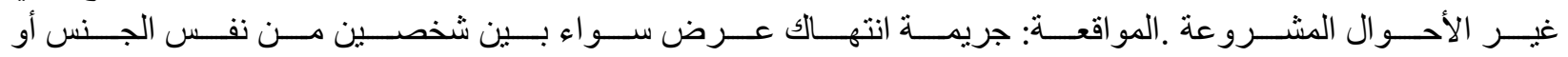
جنسين مختلفين. 


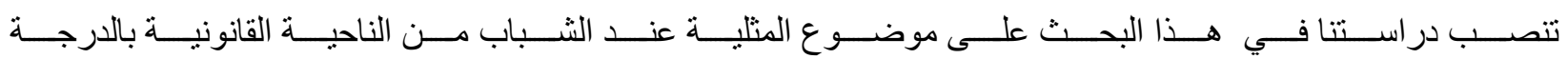

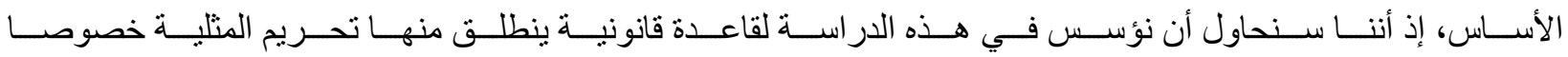

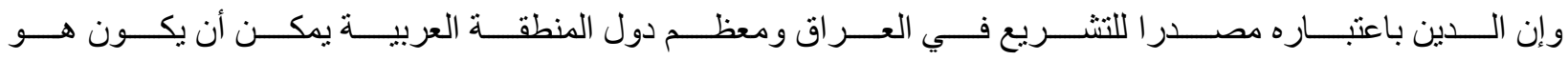
الأساس الذي يقوم عليه هذا المنع القانوني، وسيكون ذلك من خلال:

\section{أولا: موضوع البحث}

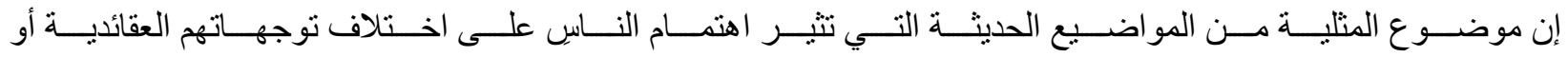

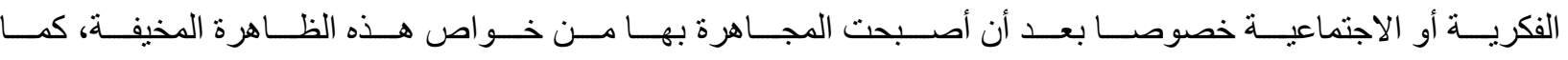

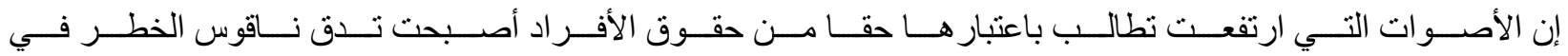

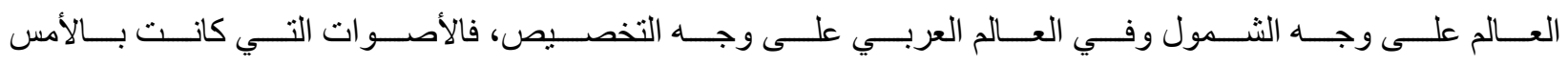

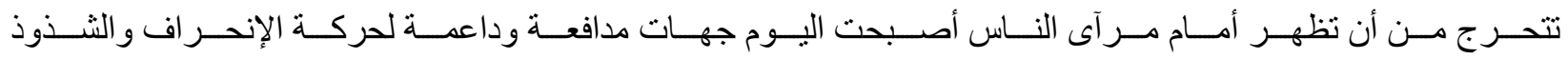

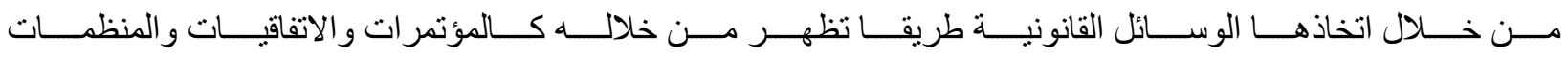
المعنية بهذا النوع من العلاقات المحرمة. ثانيا: أسباب اختيار موضوع البحث

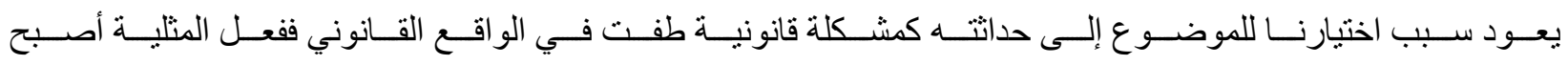

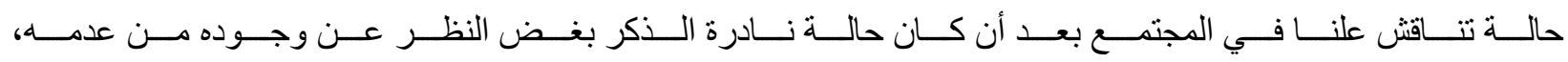

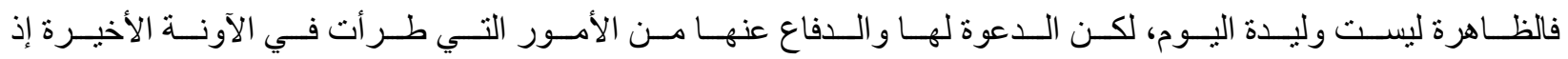

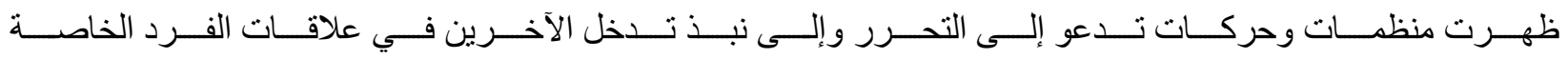

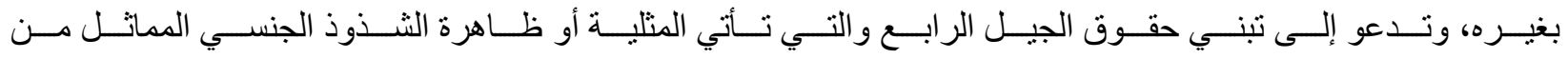

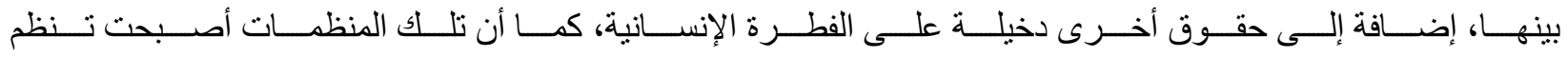

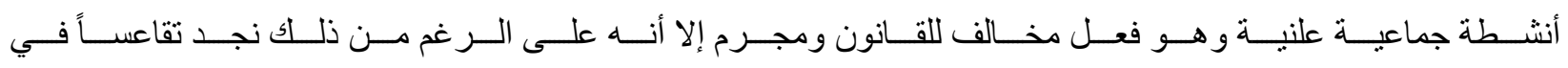

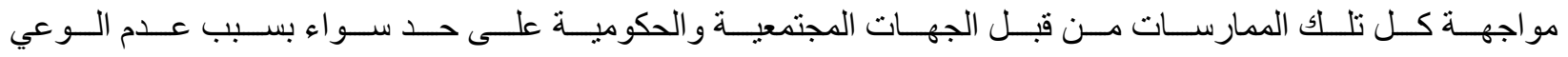

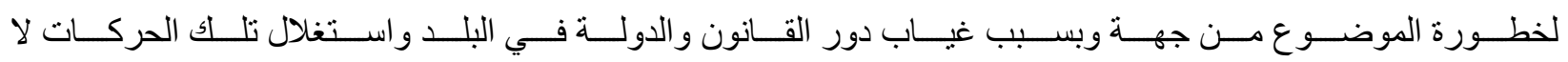




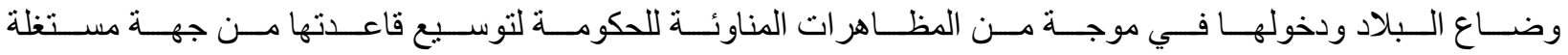

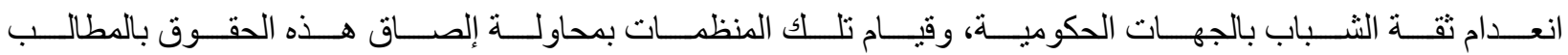
الأساسية للشعب و التستر بغطاء المظلومية لنشر هذه الأفكار ...

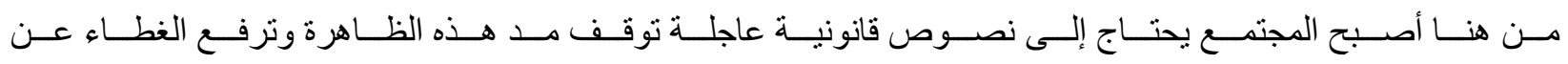

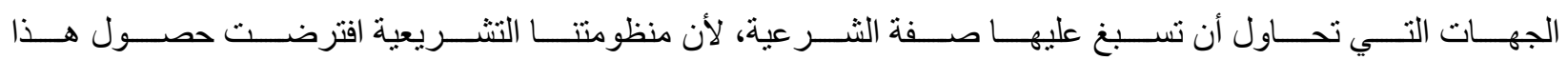

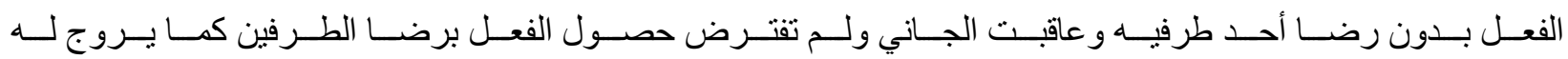

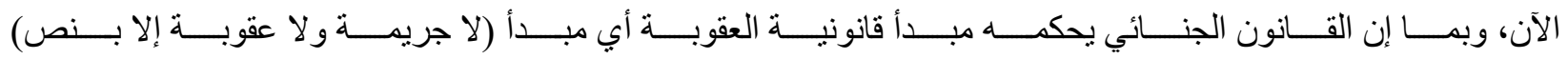

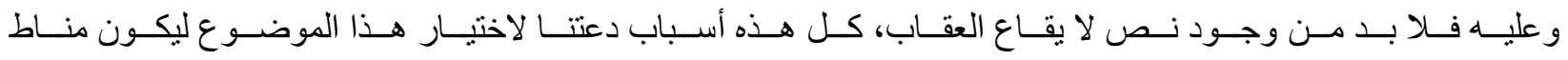
بحثنا.

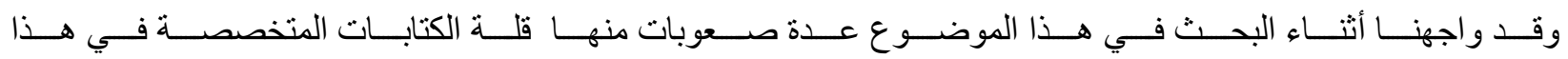

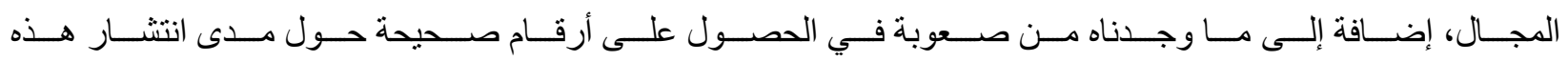
الظـــاهرة، لعــدم وجــود الإحصـــاءات الرســمية مــرة ، أو لتضـــيم الجهــات الداعمــة للثـــذوذ الجنســي لــبعض

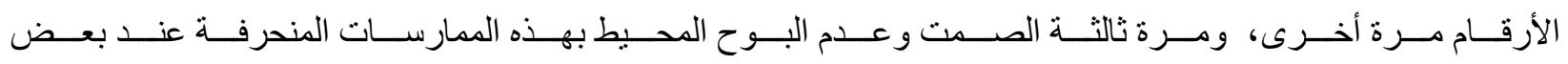
المجتمعات .

\section{ثالثا: منهجية البحث}

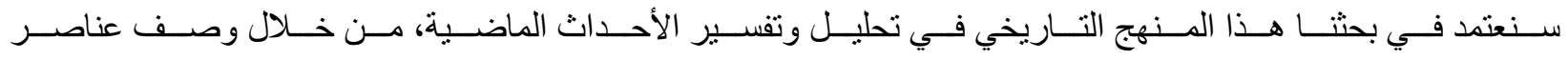

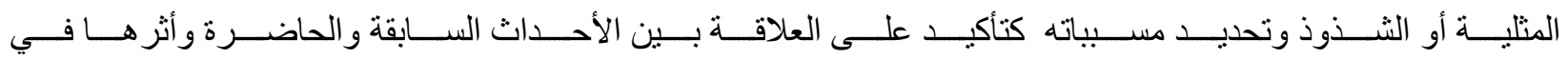

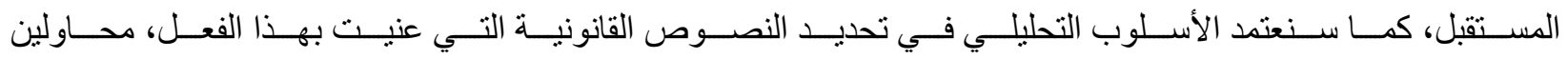

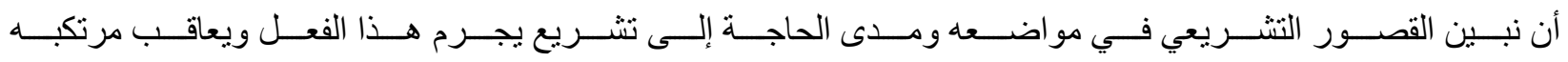
عقوبةً تتناسب مع الخطورة التي يشكلها هذا الفعل على المجتمع.

رابعا: خطة البحث

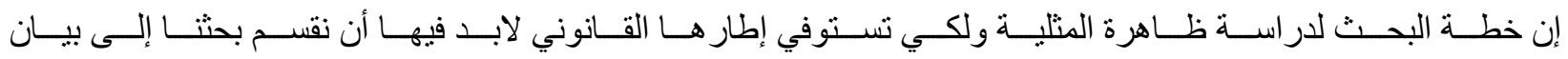

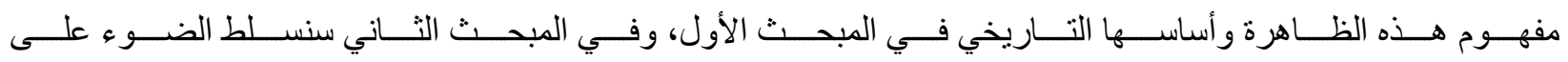




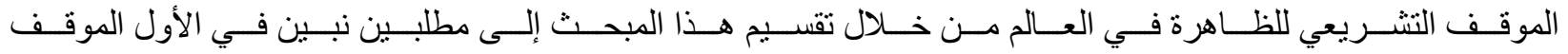

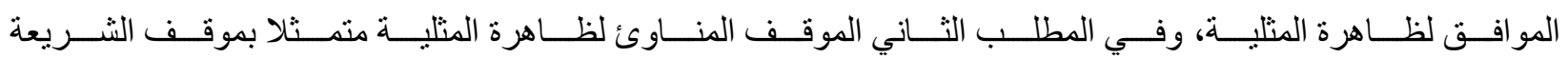

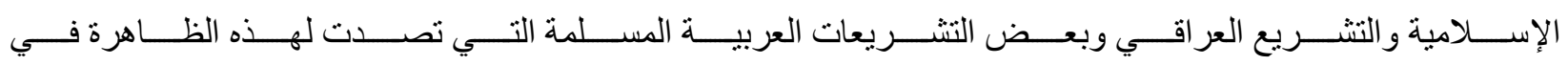
قو انينها.

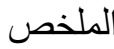

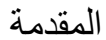

المبحث الأول: مفهوم ظاهرة المثلية المطلب الأول: التعريف بظاهرة المثلية المطلب الثاني: الأساس التاريخي لظاهرة المثلية المبحث الثاني: الموقف النشريعي من ظاهرة المنلية المطلب الأول: الموقف الموافق لظاهرة المنلية المطلب الثاني: الموقف المناوئ لظاهرة المثلية الخاتمة: مقترحات توصيات

\section{مفهوم ظاهرة المثلية}

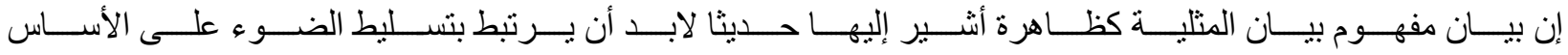

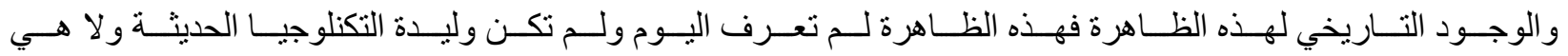

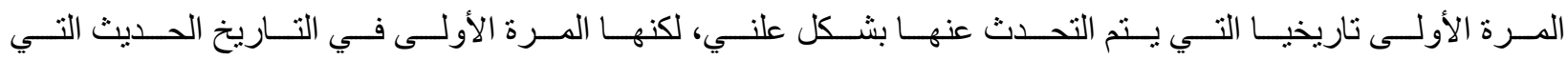

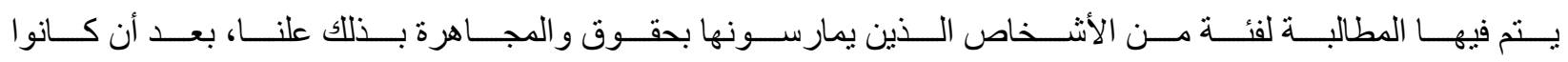

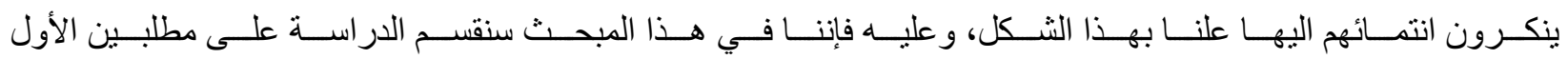

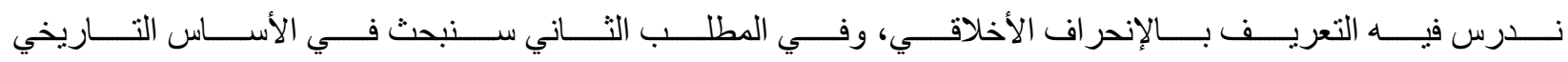

$$
\text { للانحر اف الخلقي. }
$$




\section{التعريف بظاهرة المثلية}

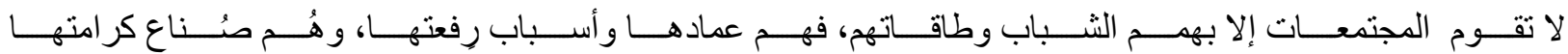

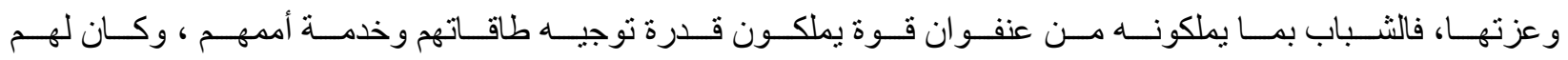

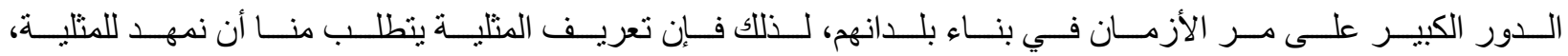

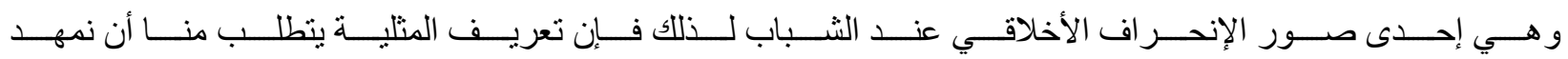

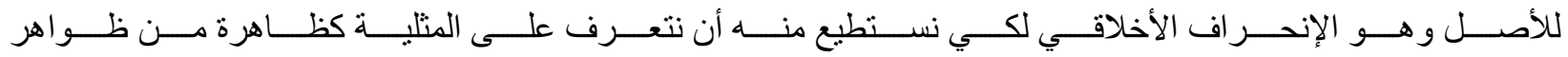
الإنحر اف في المجتمع

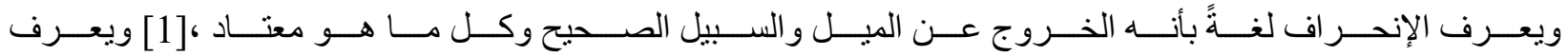
اصــطلاحاً بأنـــهـ اختــر اق التوقعــات الاجتماعيــة و انتهاكهــا، والخــروج عــن المعــايير التــي يحــددها المجتمــع ويرتضيها للسلوك و عدم الالنزام بها. [2]

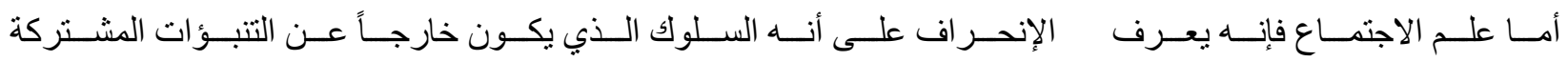

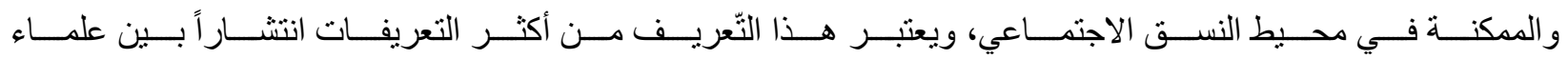
[3] [3]

فالاضـطر ابات التي تصـيب هذه الفئة تصـيبهم في هـويتهم الجنسية، تتمثل في عدم قبـول الفرد

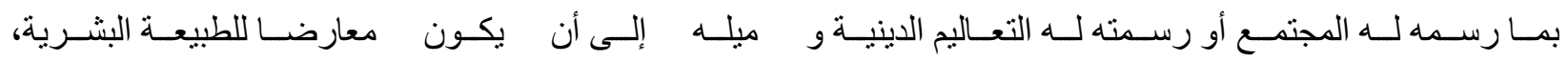

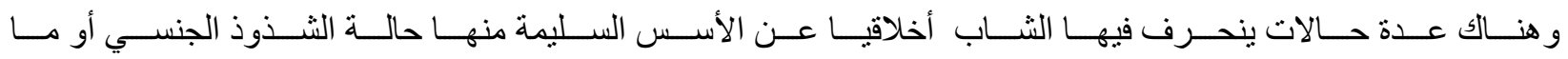
يعرف بالمثلية و هي موضو ع بحثنا.

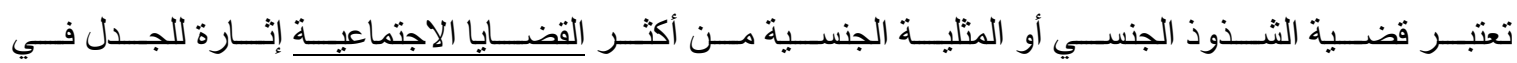

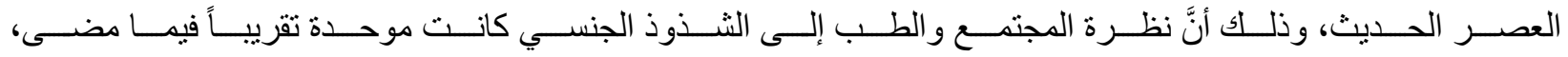

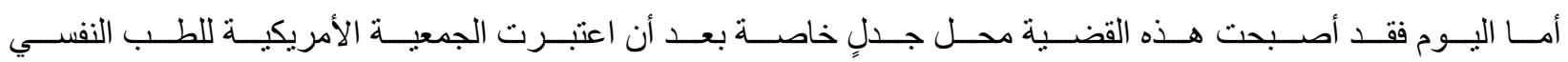

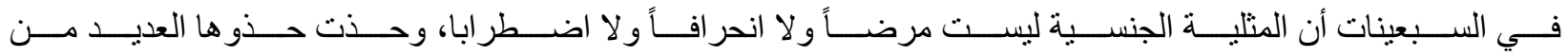




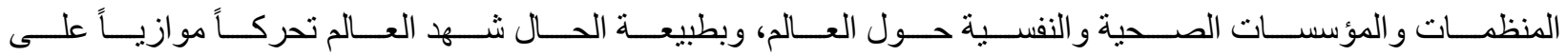
مستوى القو انين.

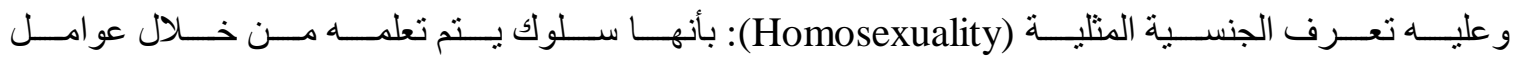
متعددة مركبة تشكل سلوك الإنسان، منها ما يكون باختياره الثخصي ومنها ما لاتكون كذلك.

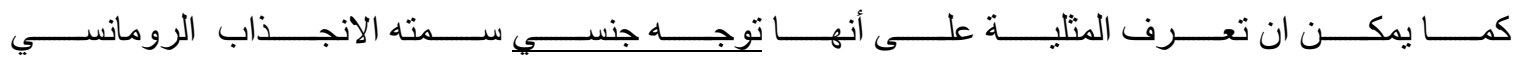

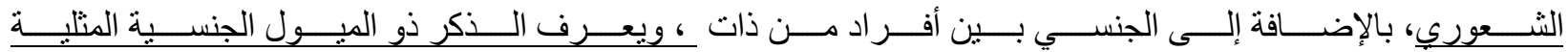

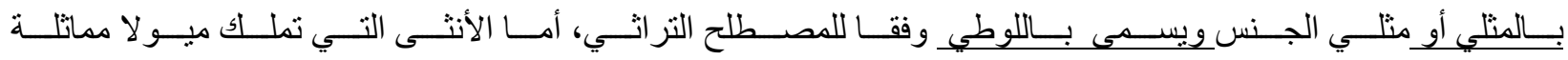

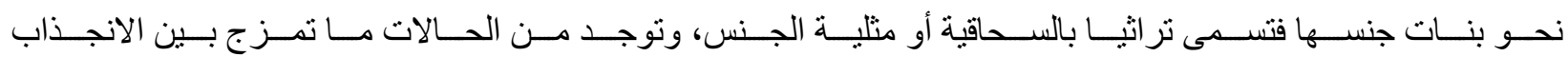
نحو ذات الجنس و الجنس الآخر وتسمى تلك الحالات بما بسمى مزدوج الميول الجنسية ـ [4]

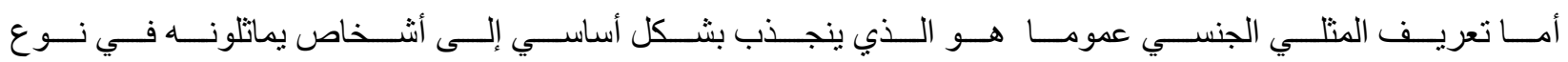

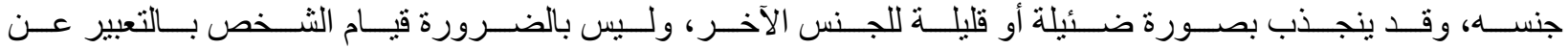

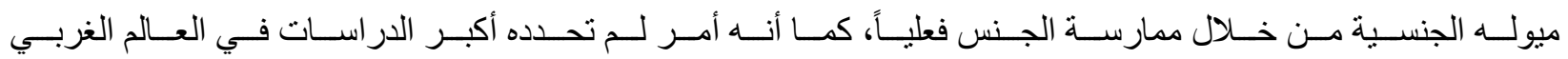

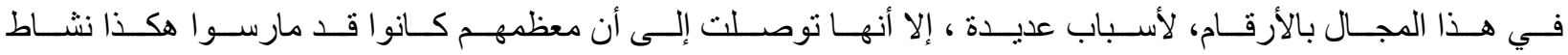

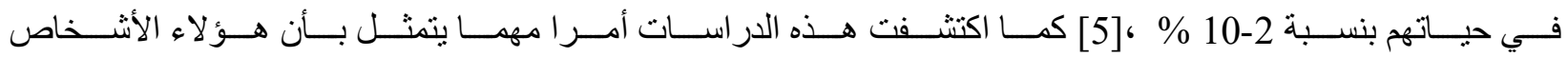

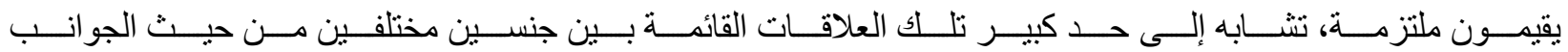
الأساسية النفسية. [6]

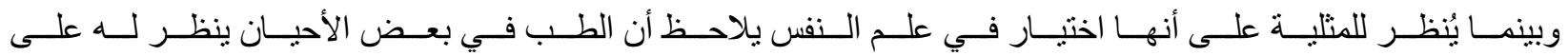

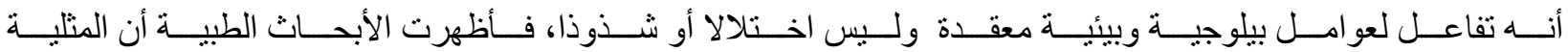

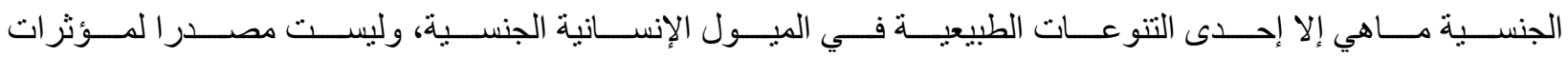

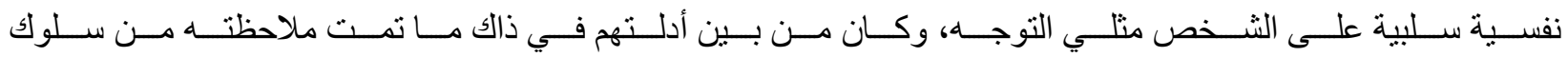
بعض الحيو انات سلوكا مثليا على حد قولهم. [7]

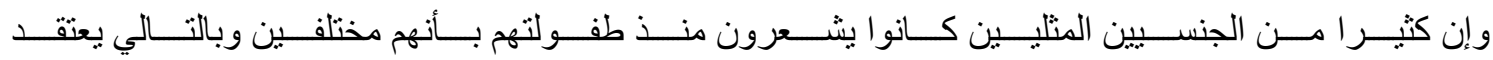

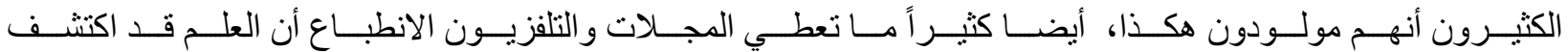

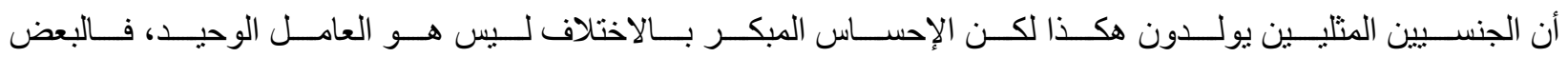

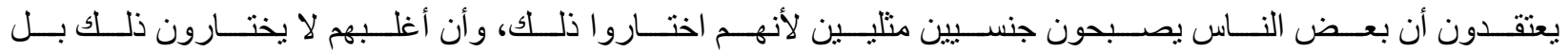




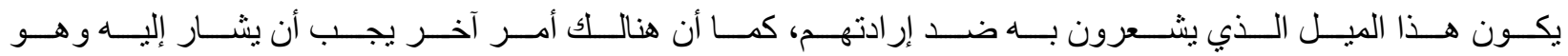

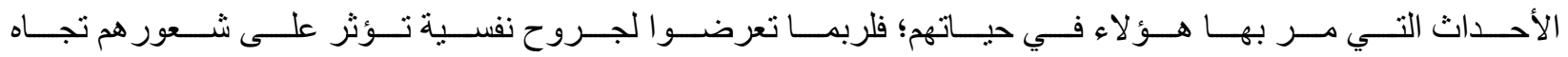

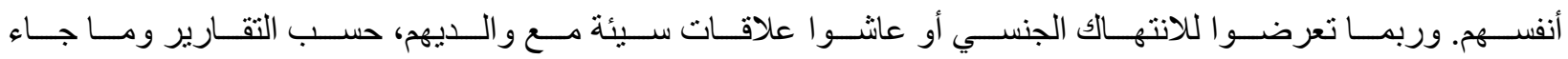

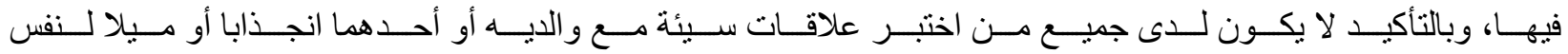
الجنس. [8]

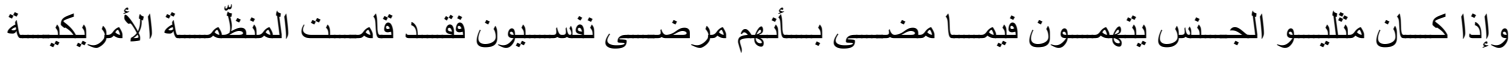
(A.P.A) 1
و والت American
Psychiatric
للأمــــر اض النفســيّة (Association)

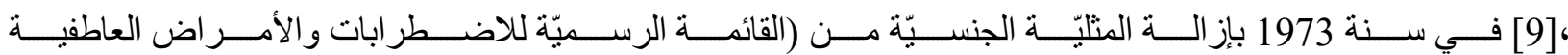

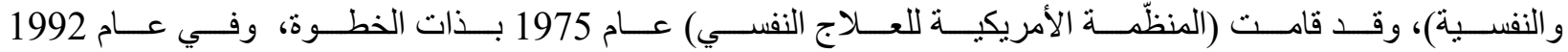

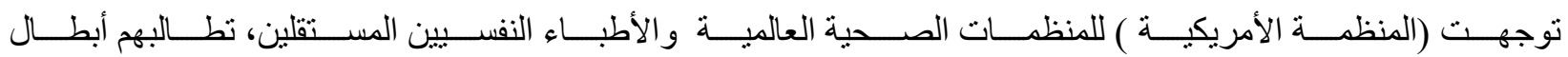

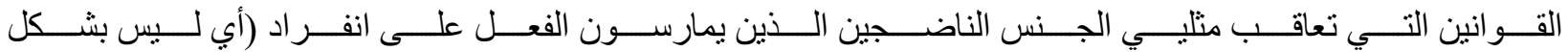
[10] عمومي)

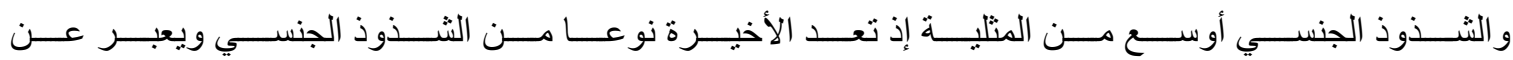

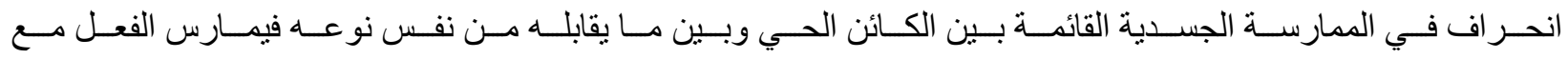

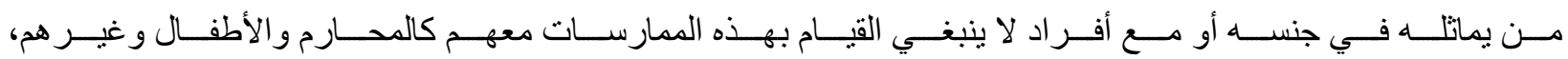
وتعـرف المتليـة على إنها بالجاذبيـة المفضـلة، لأشـخاص مـن نفس الجنس وينجذب عاطفيـا و جسـيا لا لا فر اد من نفس جنسـ.

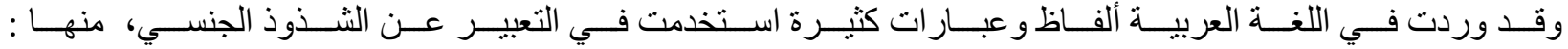

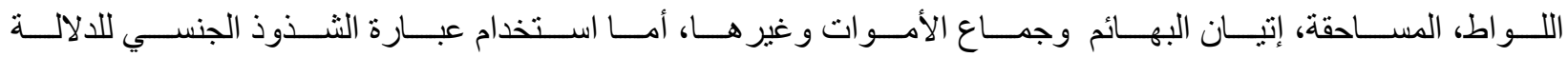

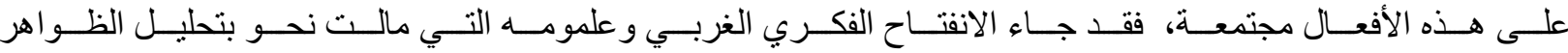

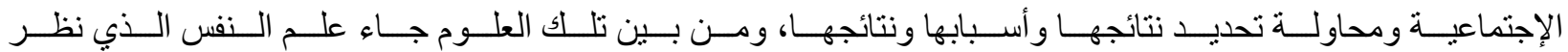

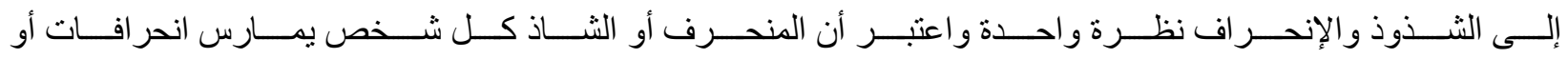
تختلف مع الأعر اف والثقافة العامة لمجتمعه أو بيئته. [11] 


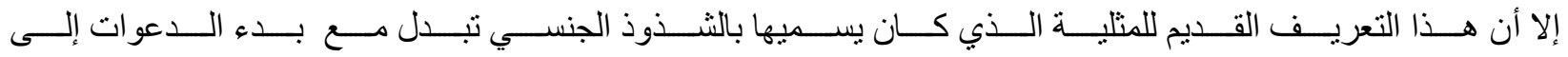

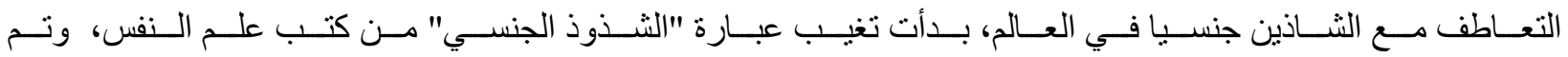

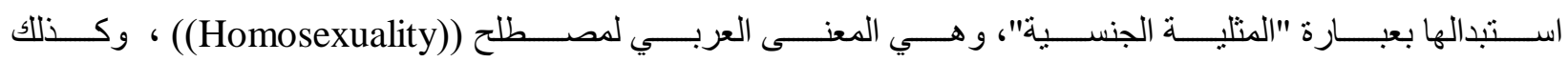

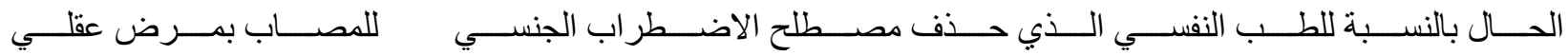

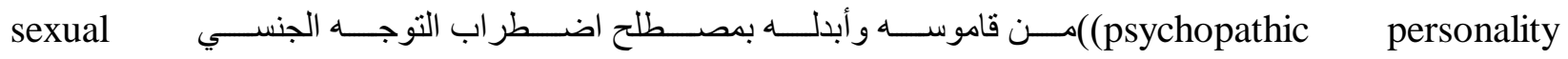
[12] .(orientation disturbance))

ولايوجد لدى المثلي الإحسـس بالانتمـاء للجنس الآخر، فهو مدرك جيـا أنسه منتمسي لجنسـه البيولـوجي ولـيس لديـه اضـطراب في الهويـة الجنسية، لـذلك فـان المنلـي يمسارس دوره العـائلي والاجتمـاعي المنوط بـه في مجتمعـه، ولا يحول سلوكه الثـاذ دون أن يكون أبـا أو أمـا في أسرة طبيعيـة، و هنالك عدة أسباب نؤدي إلى دفع الثاب لطرق الانحر اف منها :

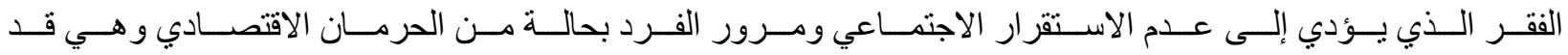

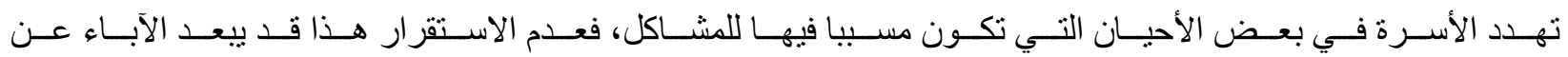

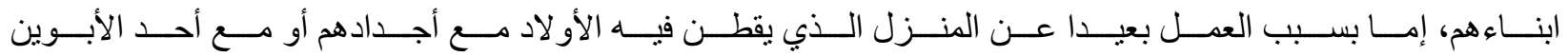

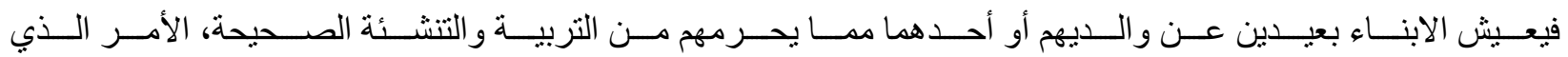
قد يجعل سلوكيات منحرفة تنمو لدى الطفل لا ينتبه لها الو الدان لتقويمها.

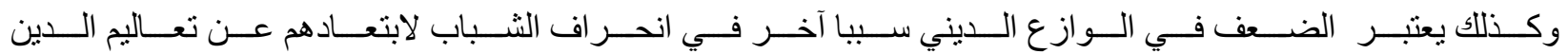

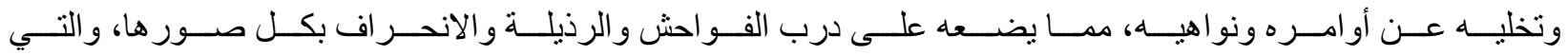

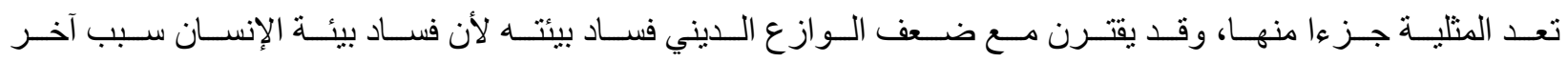

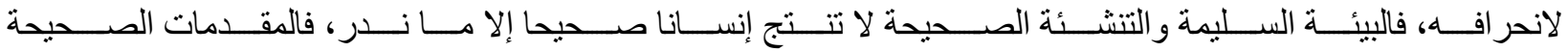

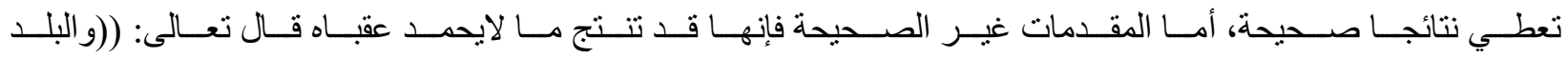

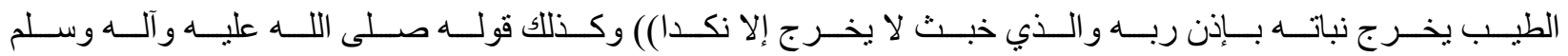
عن خضر اء الدمن : ((هي الحسناء في منابت السوء)). [13]

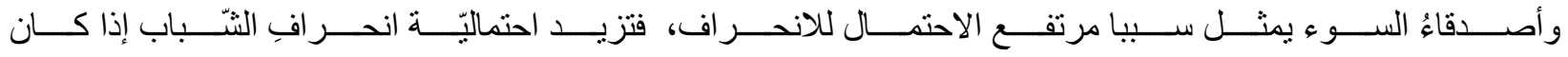

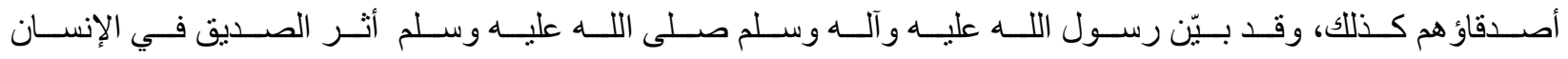




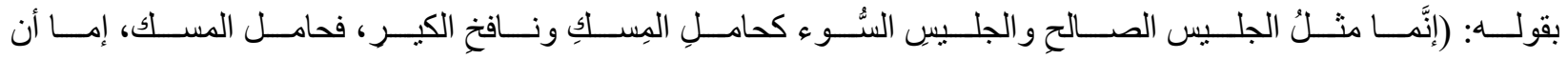

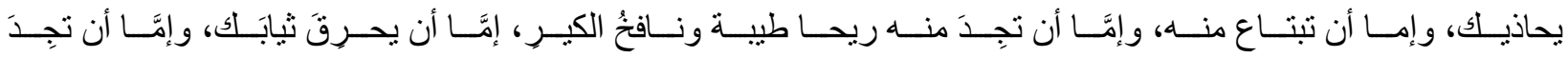

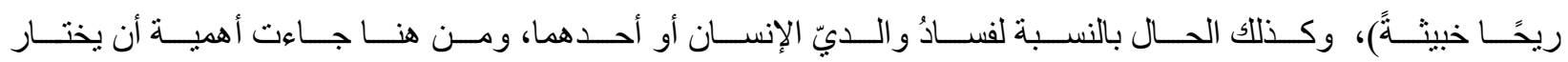

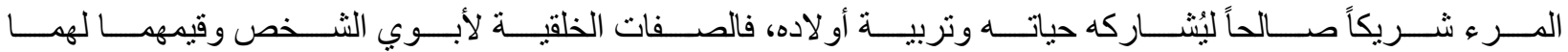

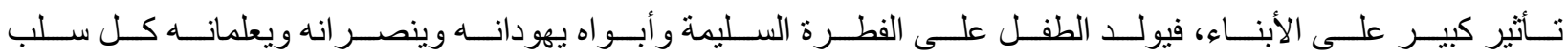

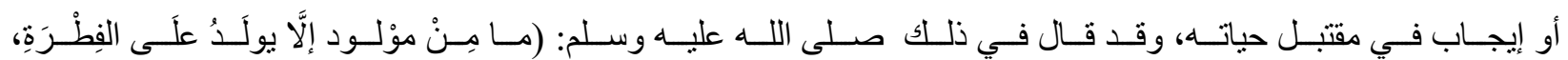
فأبو اهُ يهودانه أو ينصِر انه..... كما تتنج البهيمة بهيمة جمعاء هل تحسون فيها من جدعاءً). [15]

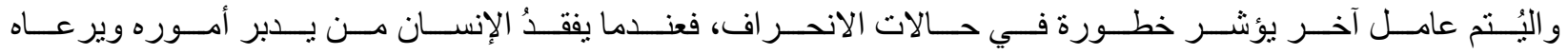

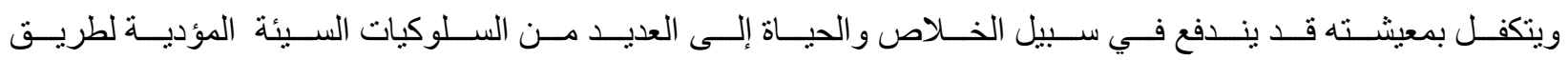

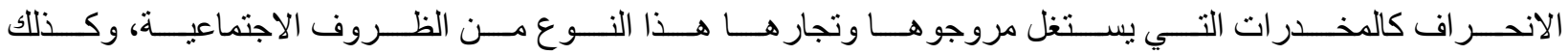
عصابات السرقة و التسول و غير ها.

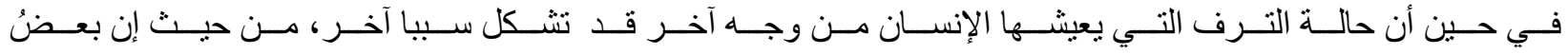

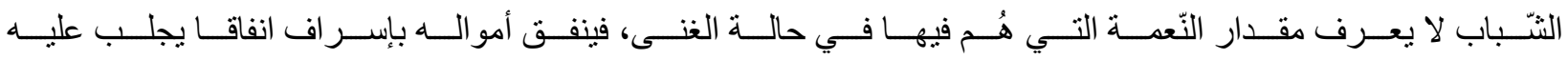

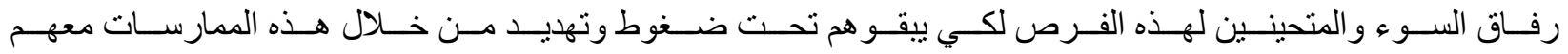
الأمر الذي يتطور في النهاية ليصبح انحر افا دائما.

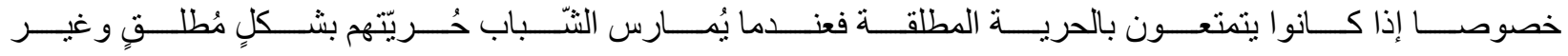

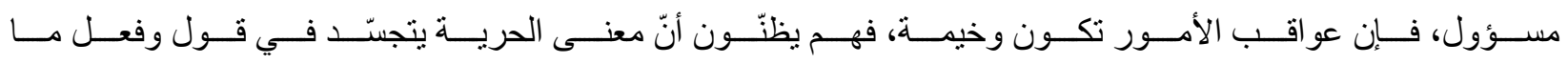

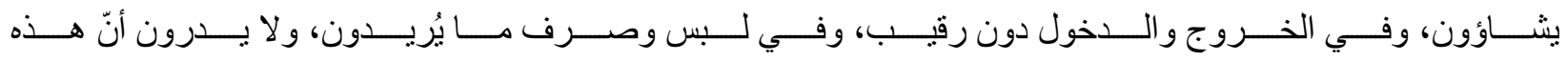
المفاهيم الخاطئة موصلة لطريق الانحر اف. [16] المطلب الثاني

الأساس التاريخي لظاهرة المثلية

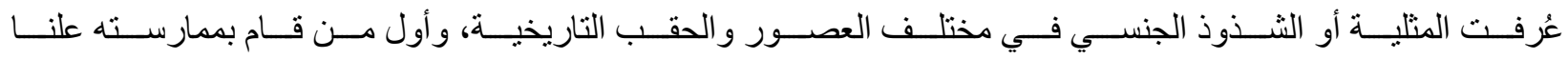

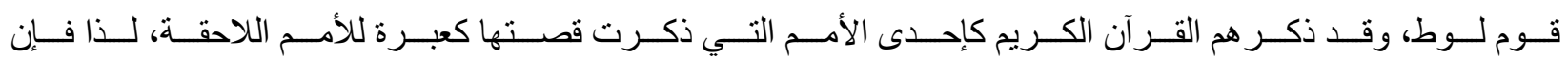




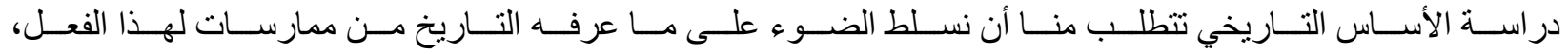

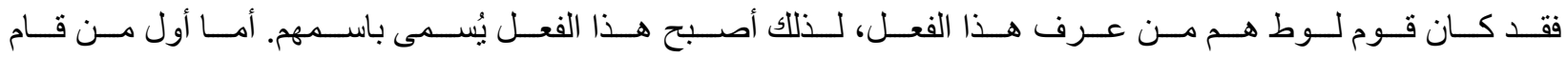

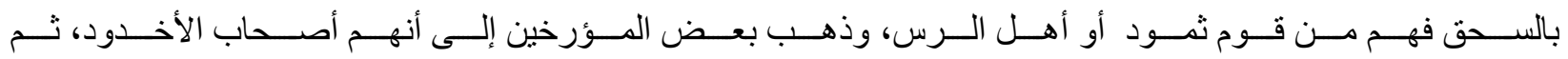

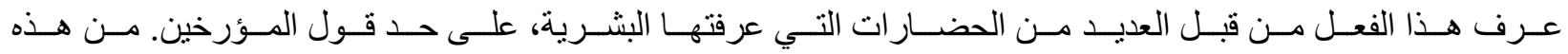
الأمم الحضارة الآشورية، و البابلية و الفرعونية، والهندية، و اليونانية، والفارسية. [17]

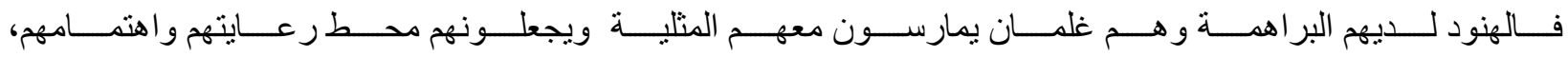

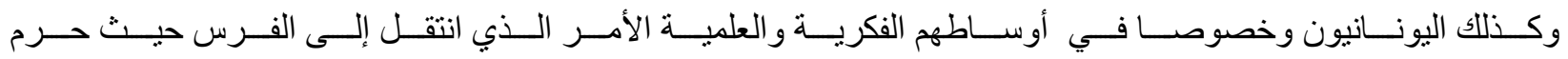
كتابهم الأفستا هذه الظاهرة ويعدها جريمة شنعاء وشذوذاً وجريمة لا يجوز الصفح عنها. [18]

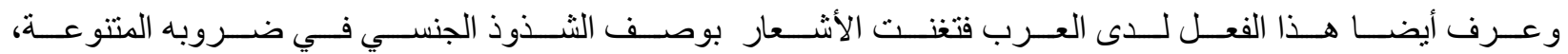

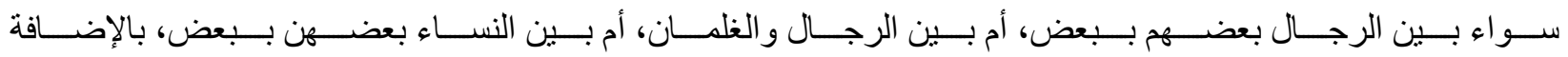
إلى تأليف كتب كانت تذكر فيها أفعال و آداب في ممارسة هذا الثذوذ. [19]

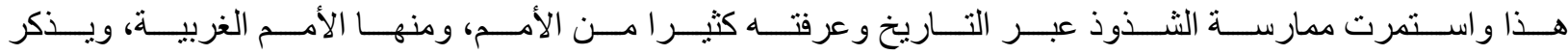

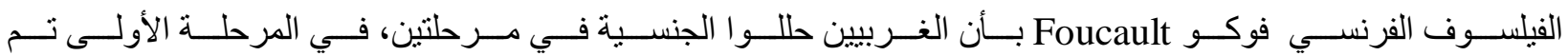

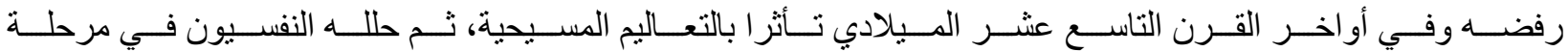

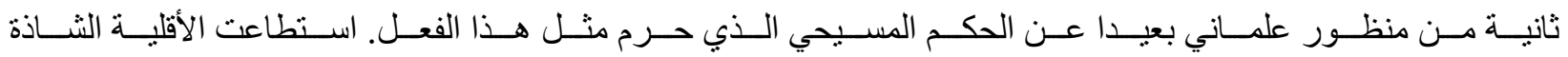

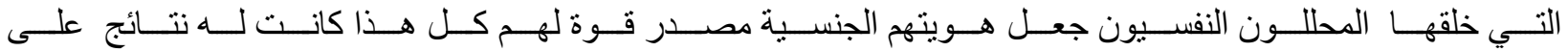

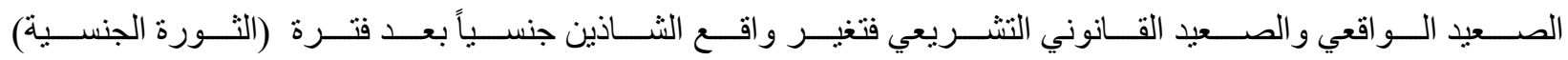

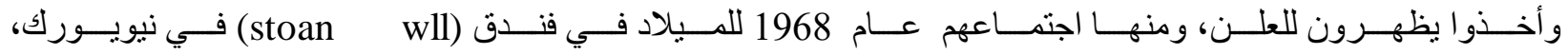

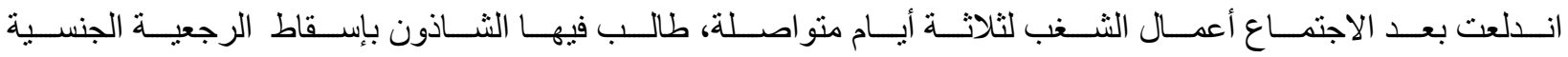

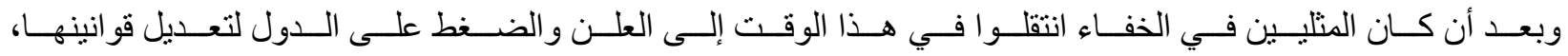

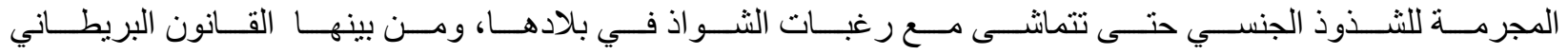

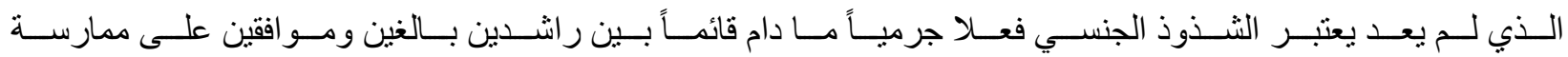




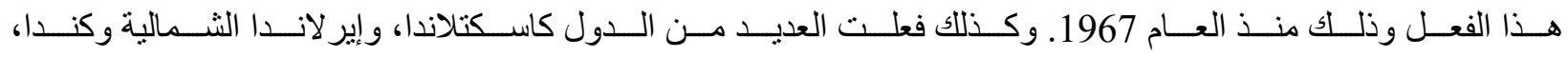

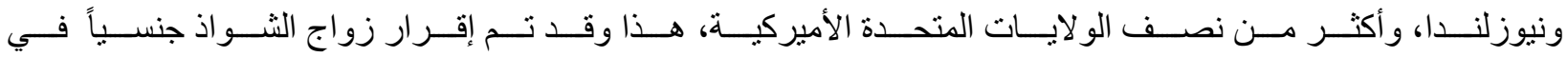

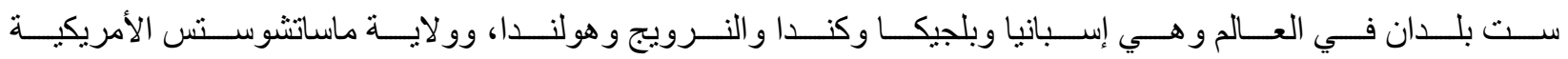
[21] [تى الآن و الرقم بتزايد مستمر

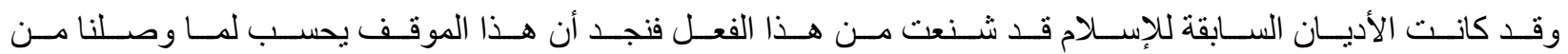

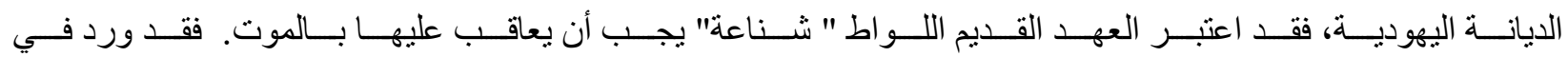

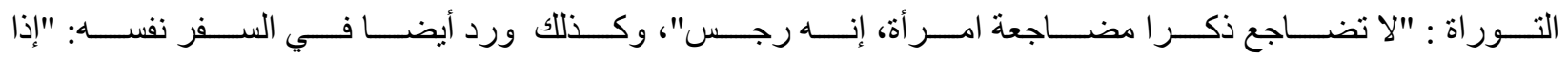
اضطجع الرجل مع الذكر اضطجاعه مع الامر أة فقد فعل كلاهما رجساً. إنهما يُقتَّلان ودمهما عليهما".

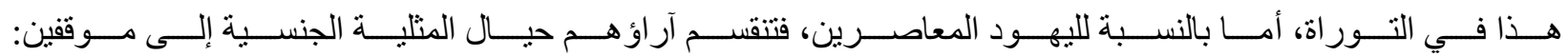

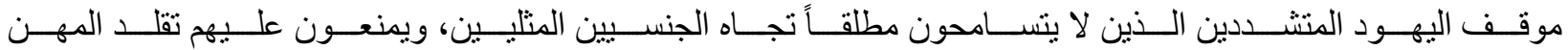
القيادية ويصرون على معاملتهم على أساس أنهم مرضى. [22]

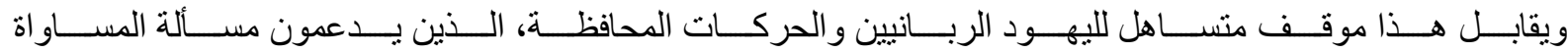

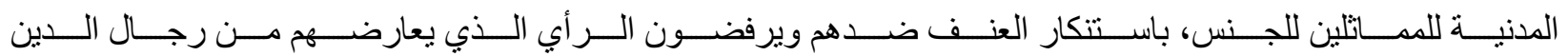

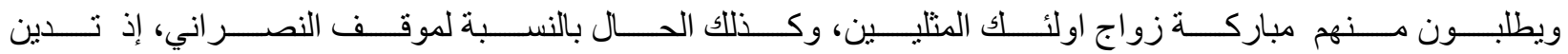

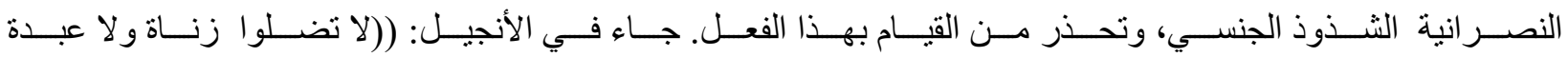
أوثَــان و لا فاســقون و لا مــأبونون و لا مضـــاجعي ذكـــور))، والجــدير بالـــكر أن الكنيســـة المســـيحية تتعـــرض لضغوطات من قبل الثاذين جنسيا من أجل تغيير مواقفها من الشواذ....

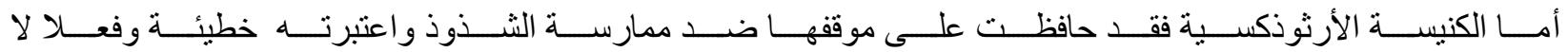

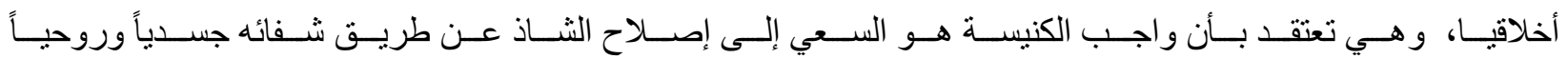
وليس العمل على مباركته لممارسته الثاذة أو تشريع قو انين تسهل له ذللك. [23] 


\section{الموقف التشريعي من ظاهرة المثلية}

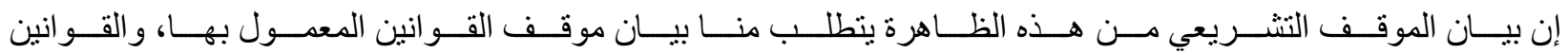

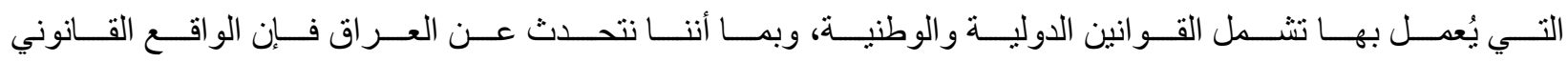

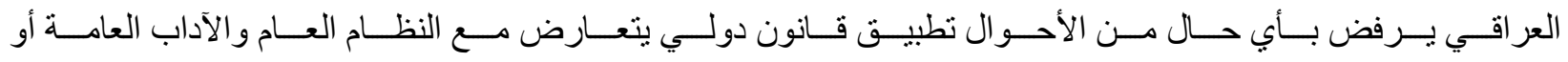

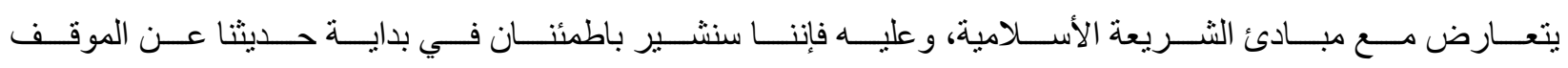

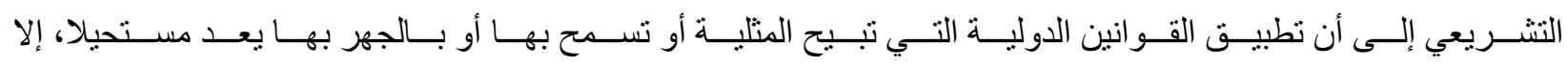

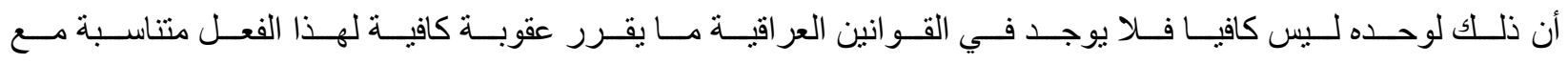

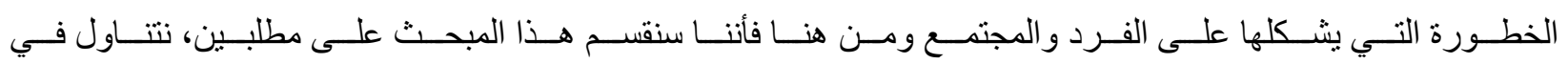

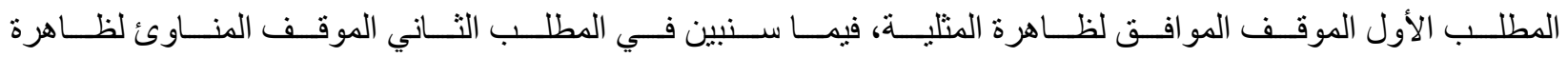
المثلية. المطلب الأول

\section{الموقف الموافق لظاهرة المثلية}

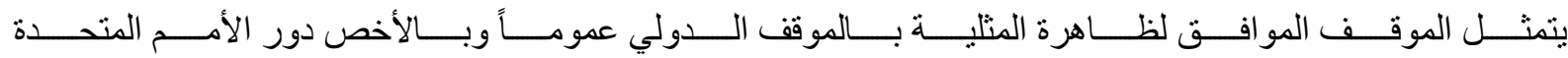

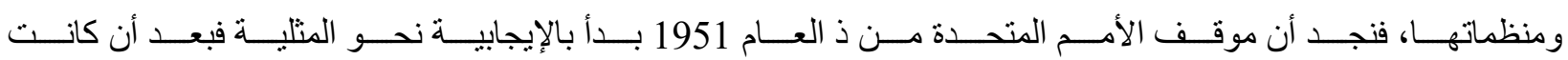

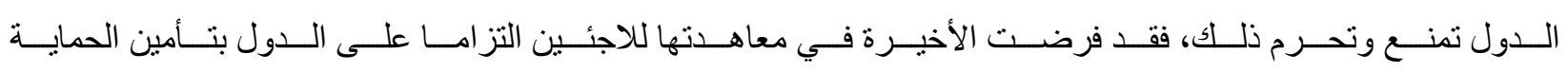

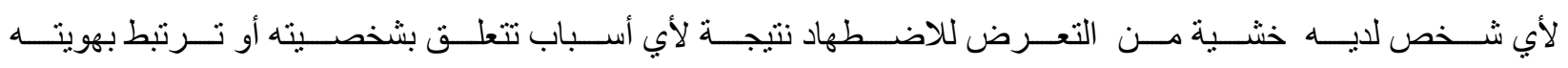
الجنسية أو انتمائه إلى أي مجمو عة اجنماعية أو سياسية .

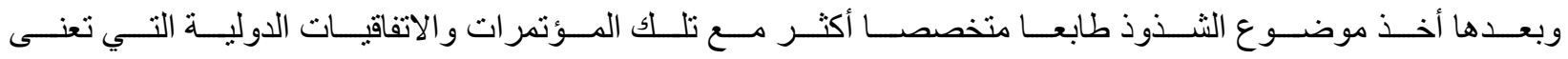

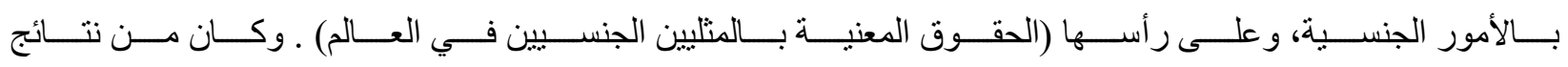

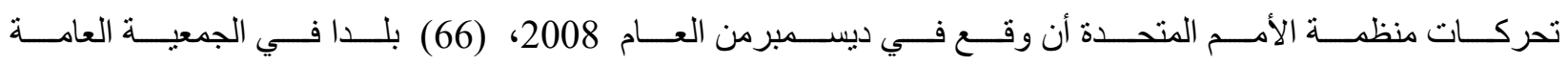
للأمم المتحدة بيانا متعلقا برفع العقوبات عن المثلية. [24] 


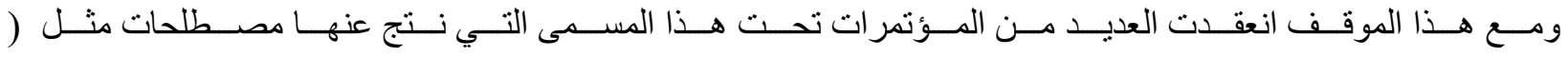

( Sexual Orientation

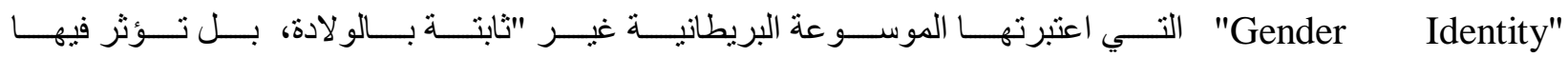
العوامل الاجتماعية والنفسية، التي تتغير بتأثثر عوامل اجتماعية عدة. [25]

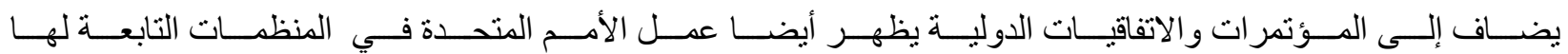
التي تعمل على تكريس هذه المفاهيم في بر امجها المتنو عة ودعمها للشاذين جنسيا بمختلف الوسائل .

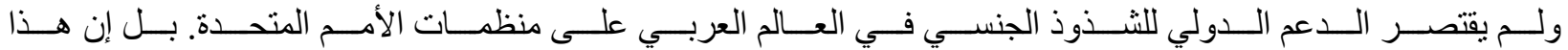

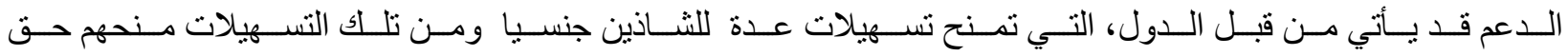
اللجو ء السياسي بناء على كونهم من المتليين.

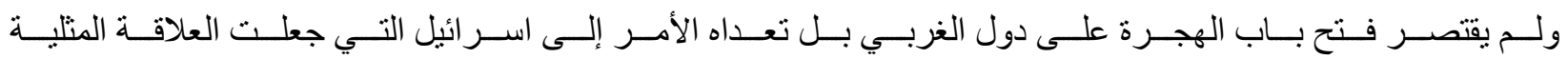

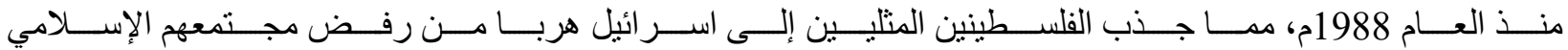

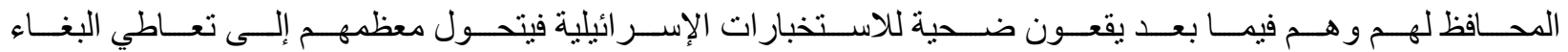
لكسب قوتهم. [26]

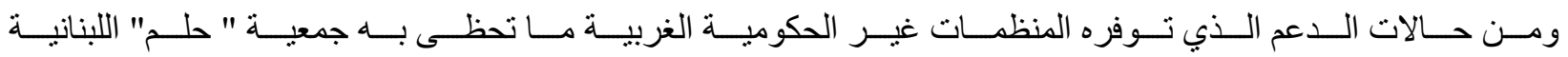

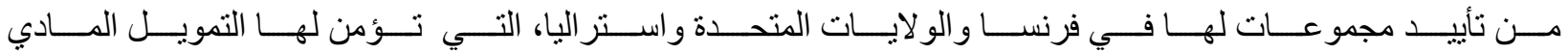

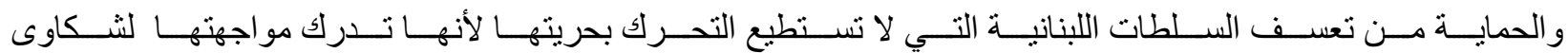
خارجية في حال اتخاذها لخطوات قمعية لهذه الممارسات الثاذة عن نظامها العام .

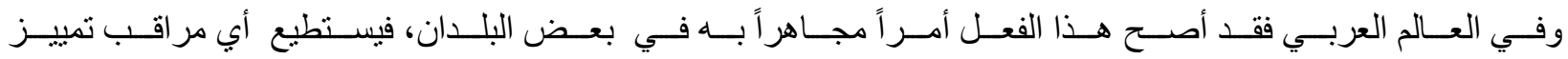

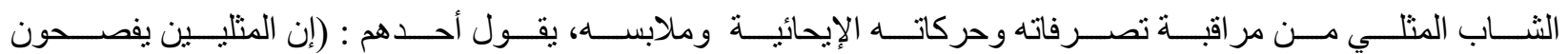

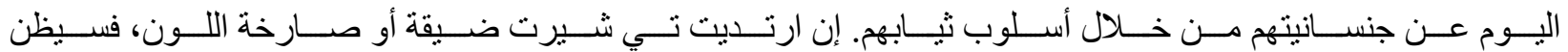

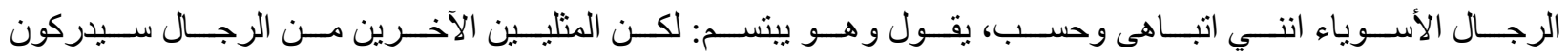




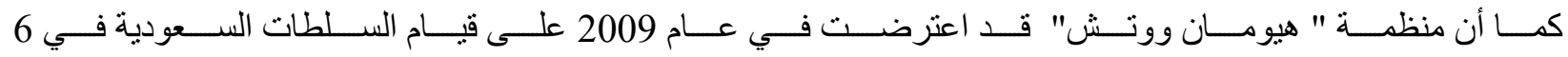

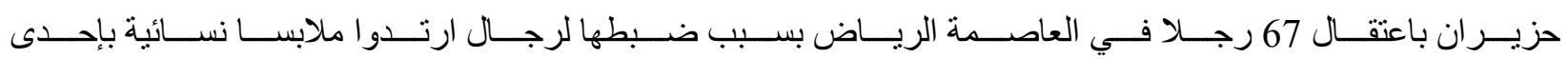
[27] [27 [الحفلات

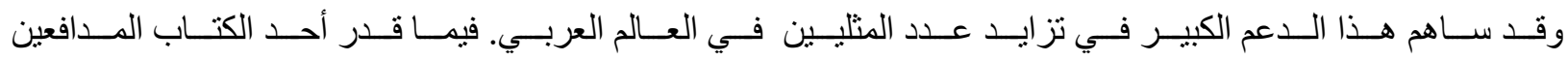

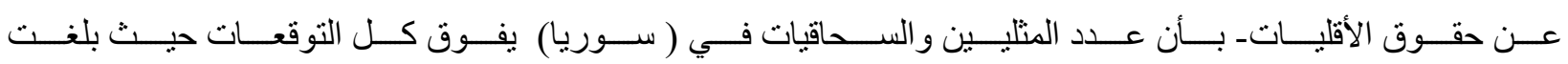

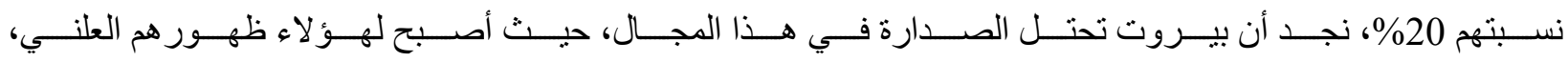

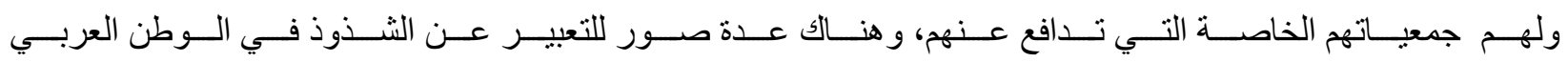

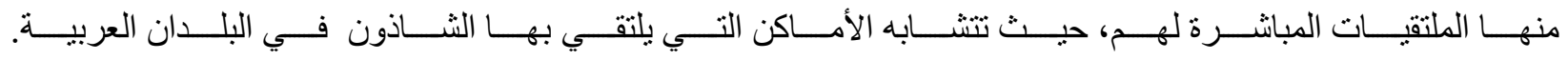

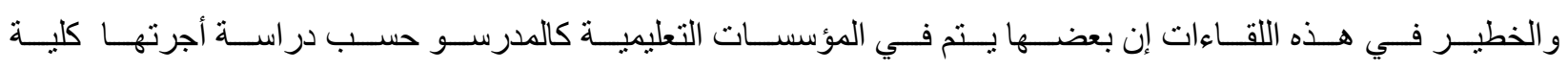
الطب في جامعة الملك عبد العزيز في جدة. [28]

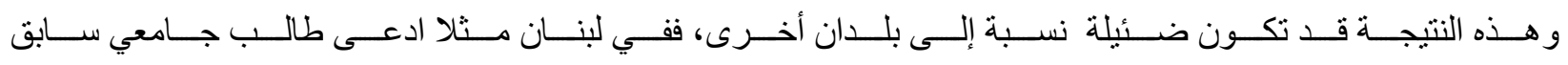

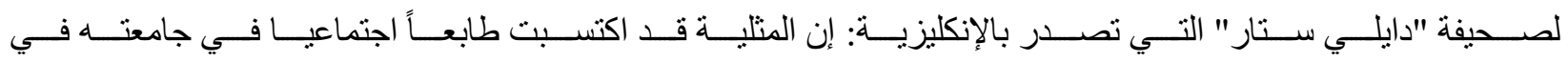

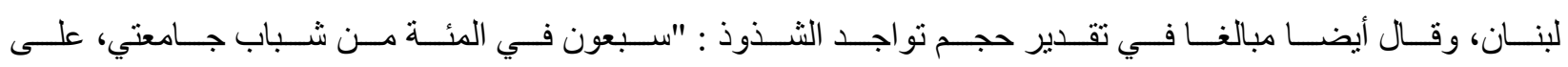

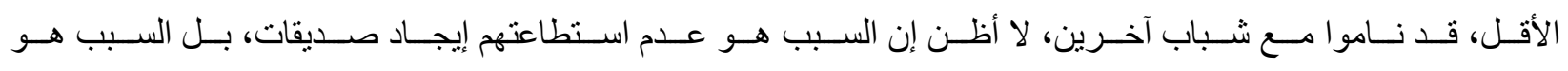
رواج الأمر فحسب.

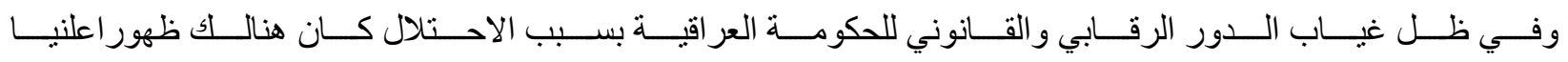

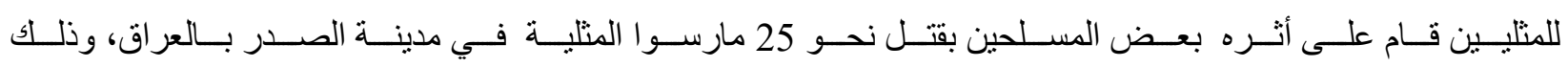

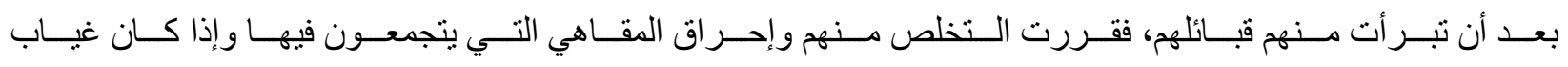

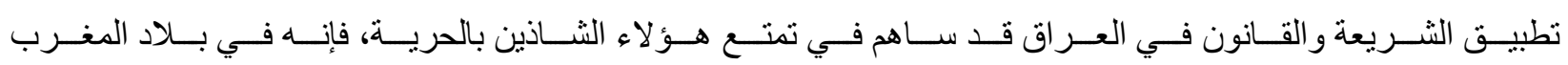

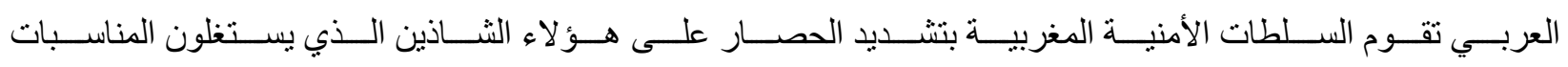
الشعبية أو الدينية من أجل ممارسة طقوسهم على مسمع ومر أى الجميع. [29]

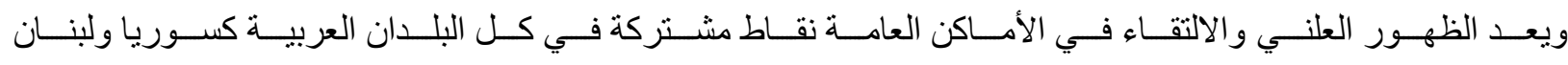

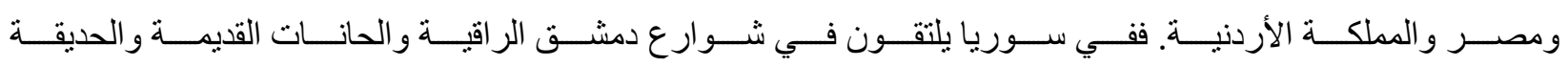




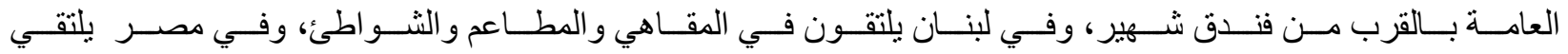
هؤ لاء في مقاهِ محددة في القاهرة كما جاء في كتاب (بلد الو لاد) للصحفي "مصطفى فتحي". [30]

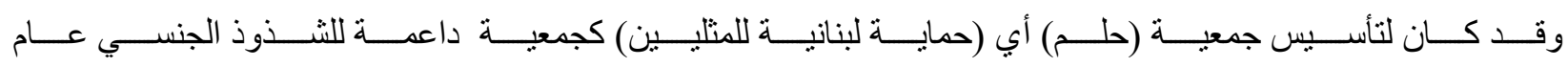
2004م كأول جمعية من نوعها في الوطن العربي، هدفها حماية المثليين، وثنائي الجنس و المتحولين.

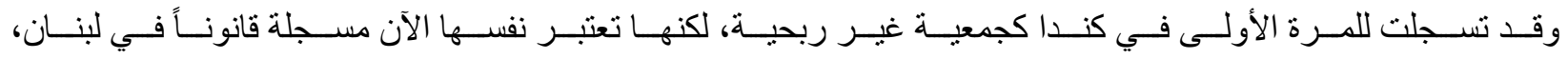

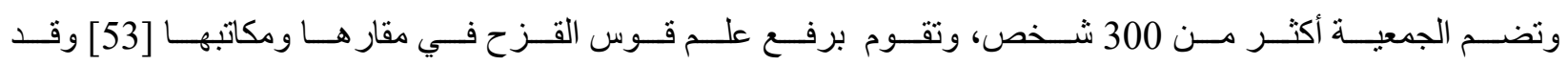

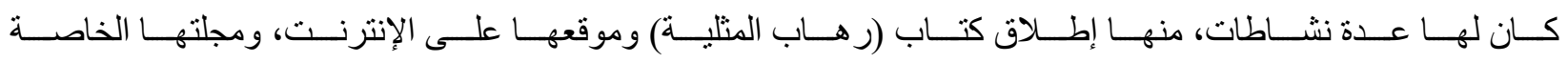

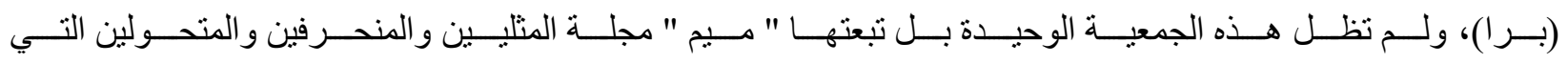
تملك أيضا موقعها ومجلتها الإلكترونيين.

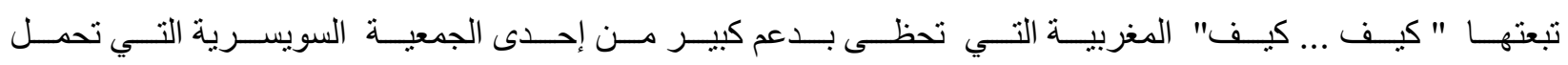
اسم "best homo"، و التي تمولها ماديا بشكل كبير. [31] المطلب الثاني

\section{الموقف المناوئ لظاهرة المثلية}

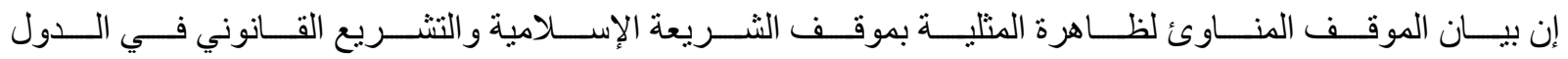

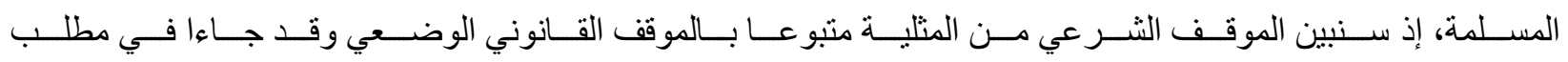

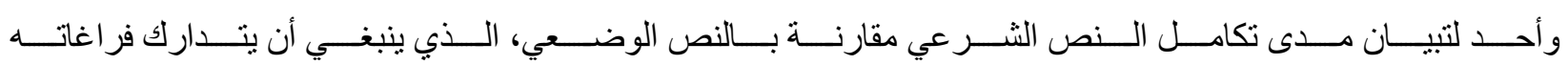

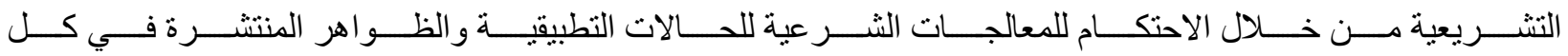

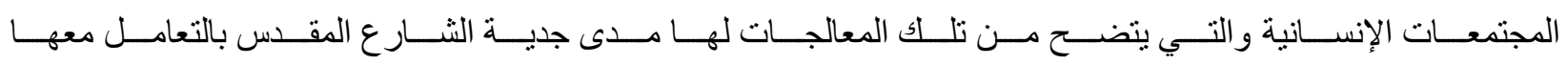

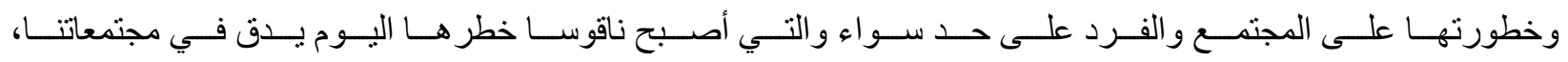

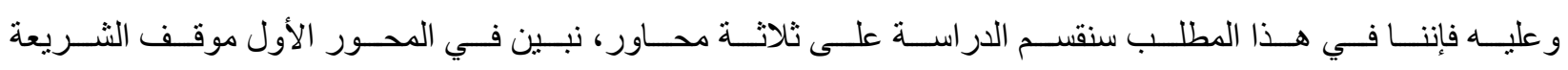

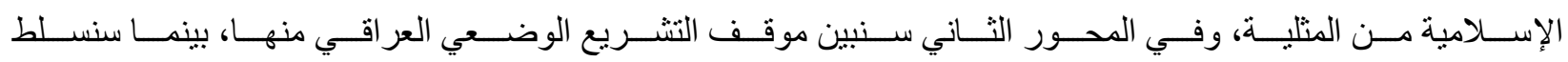

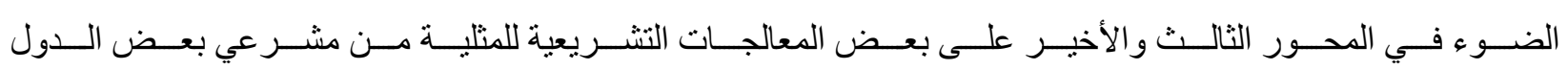




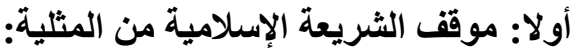

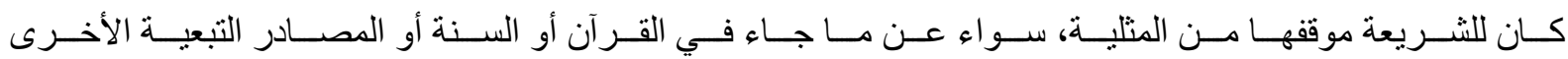

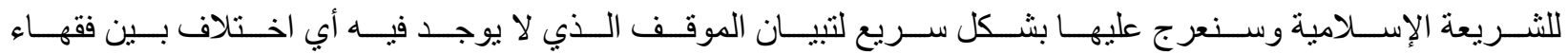

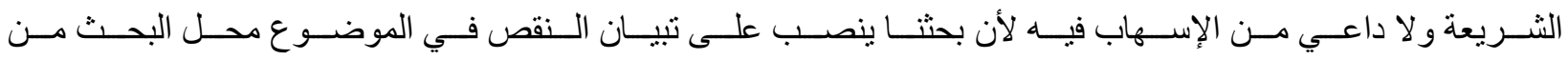
حيث النص التشريعي الوضعي مقابل الكمال التثريعي لموق الثريعة الإسلامية من المثلية.

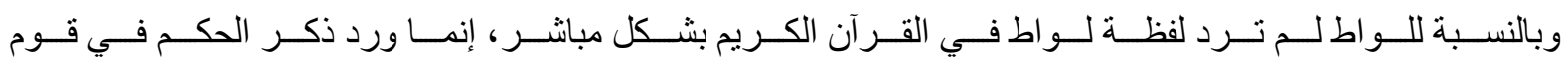

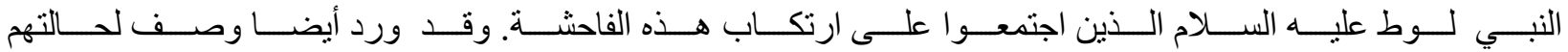

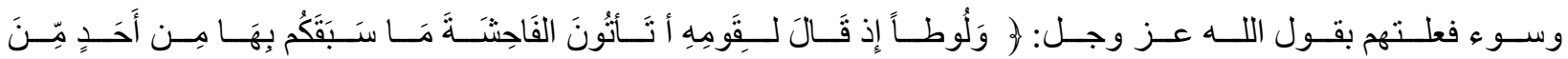

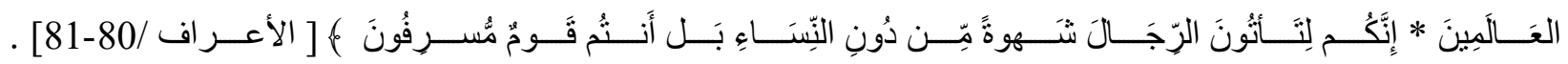

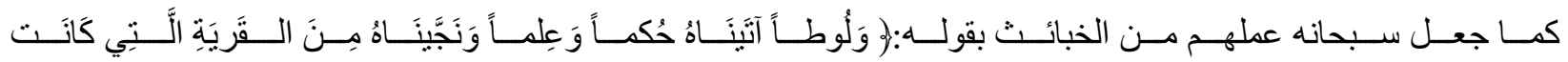

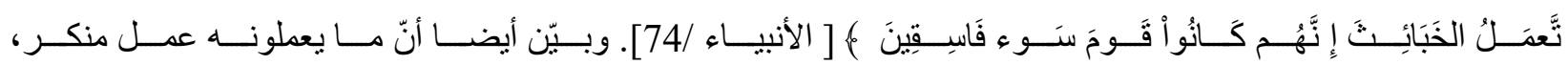

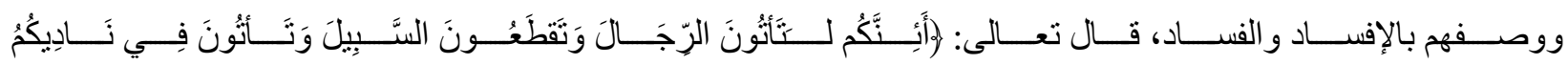

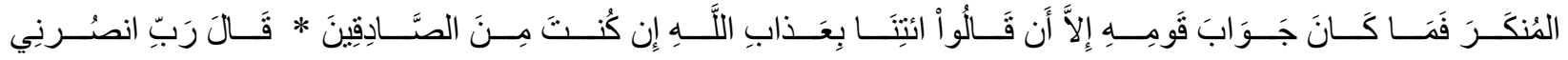

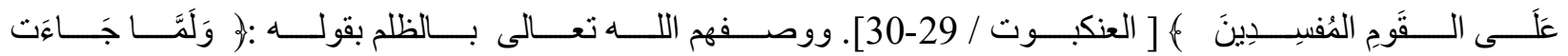

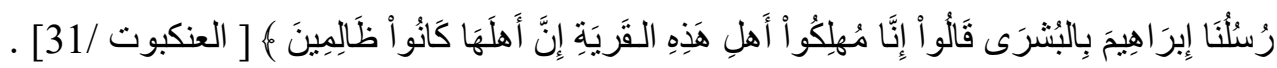

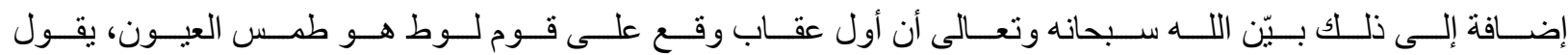

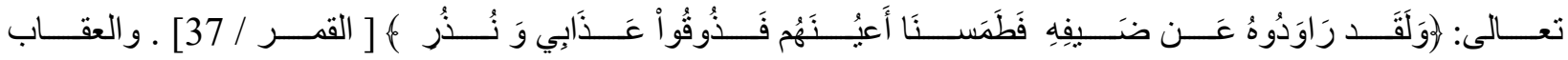

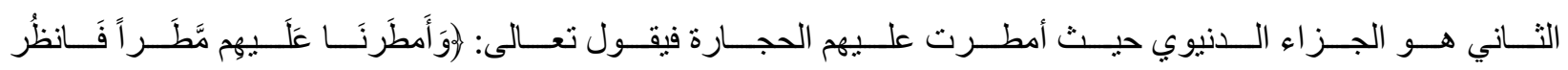

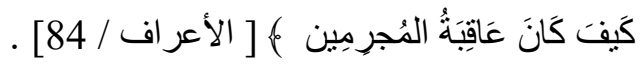

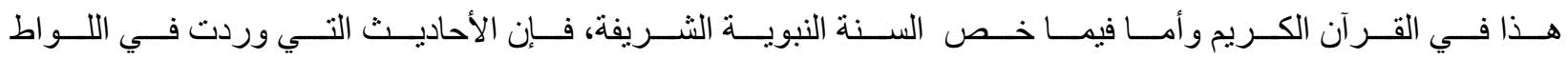

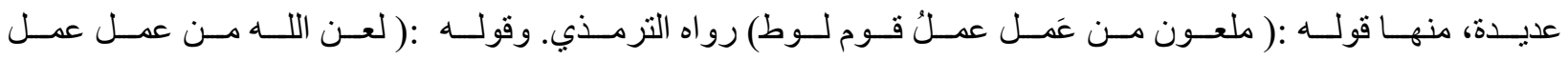
قوم لوط، لعن الله من عمل عمل قوم لوط، لعن الله من عمل عمل قوم لوط ) رواه احمد. 


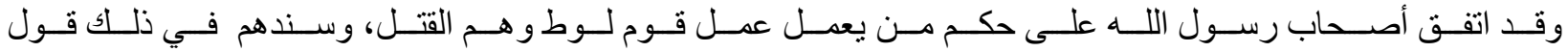
رسول الله : ( من وجدتموه يعمل عمل قوم لوط فاقتلوا الفاعل والمفعول به ) .

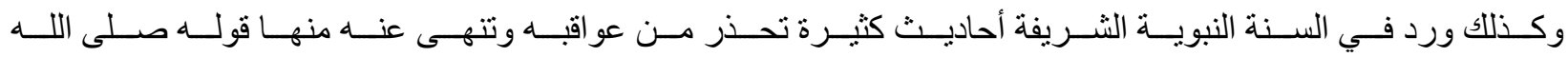

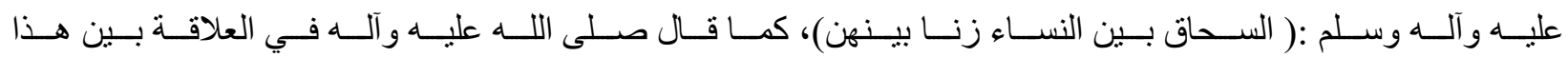

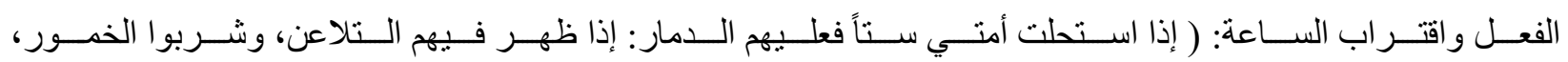

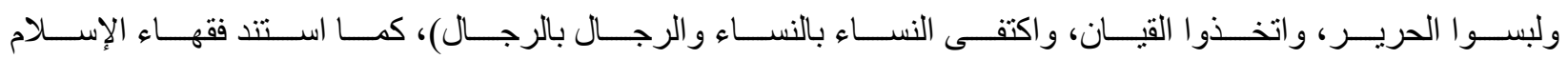

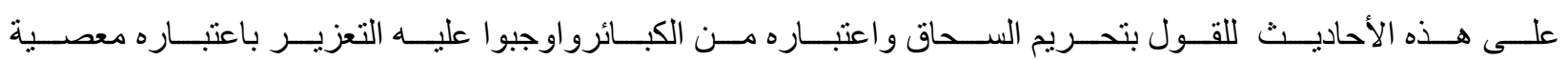
لا حد فيها و لا كفارة. [32]

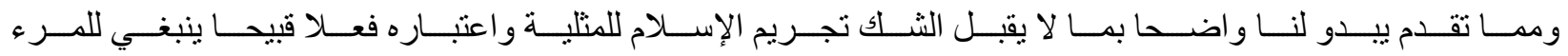

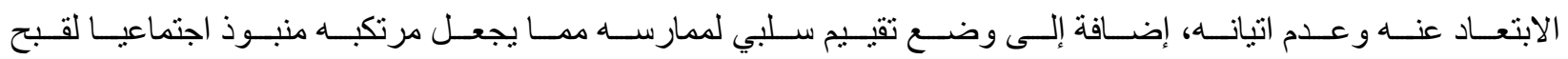

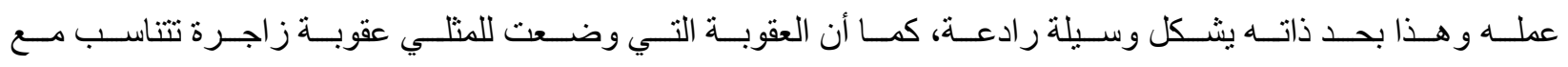
الآثار السلبية التي يأتي بها هذا الفعل الثنيع.

\section{ثانيا/ موقف التثريع الجنائي العراقي من المثلية.}

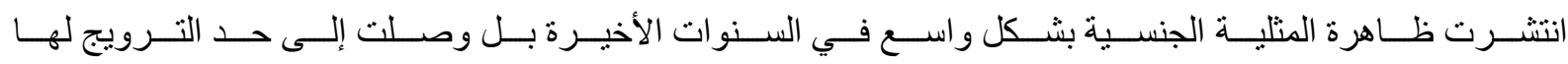

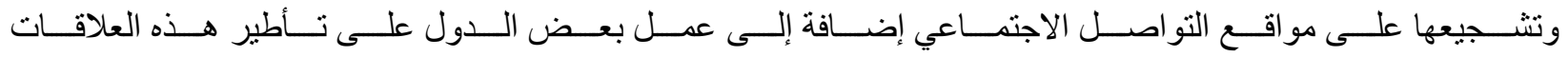

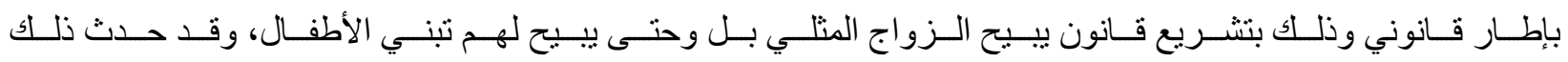

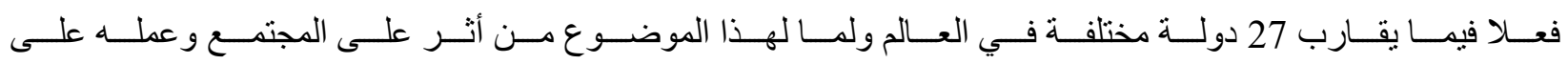

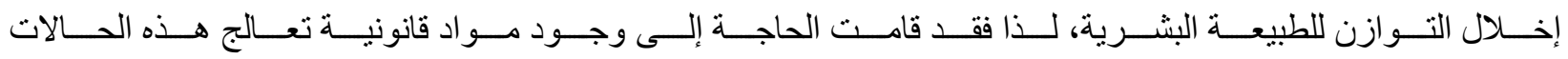

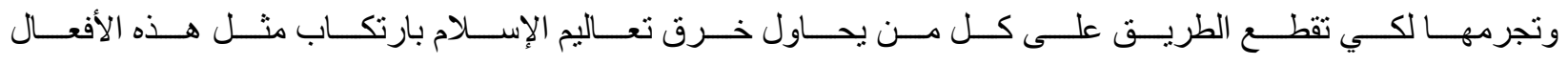

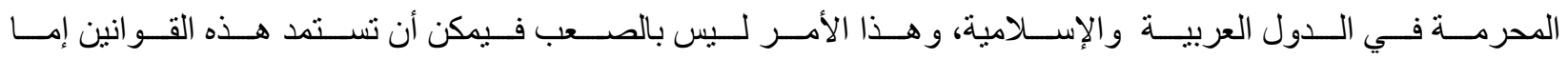

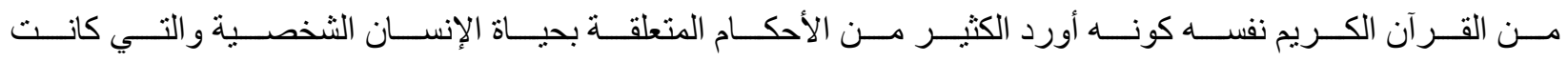




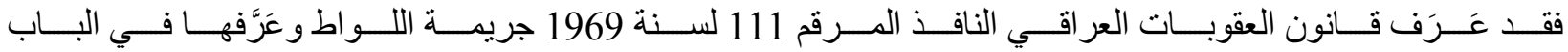

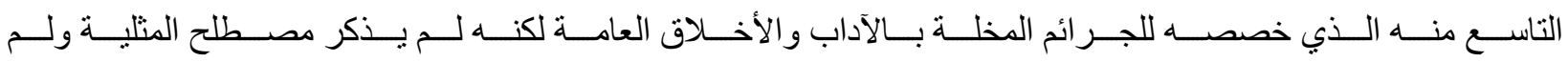

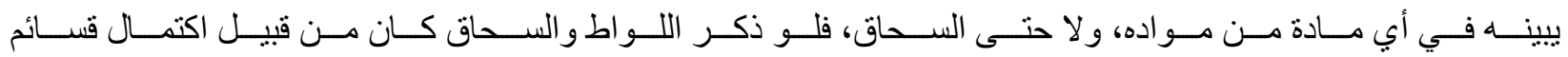

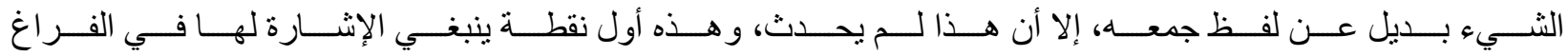
التشريعي مقابل المثلية.

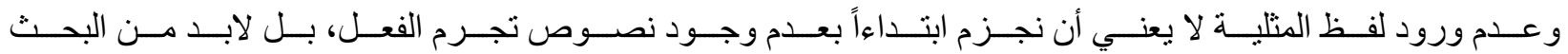
في طيات التشريع عن النصوص التي تنطبق على هذا الفعل وتجرمه.

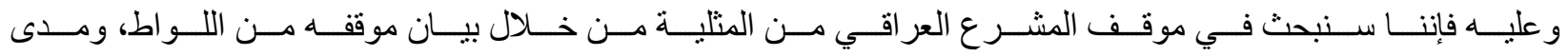

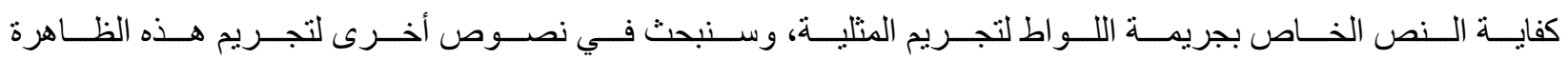

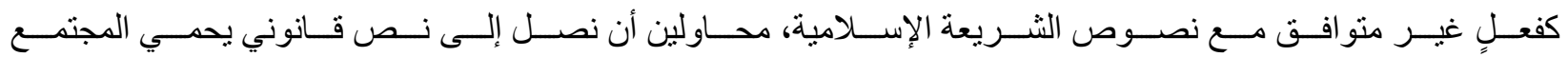
من هذه الحالة

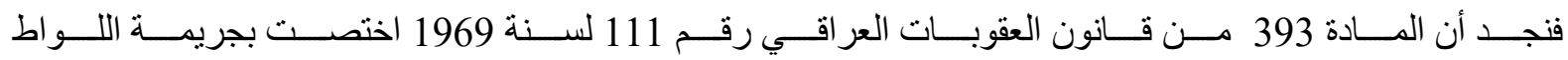

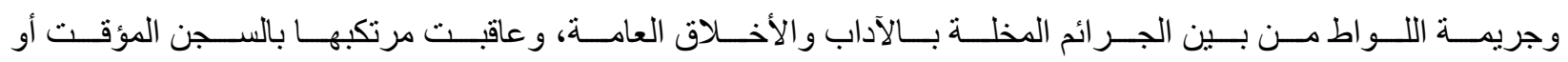

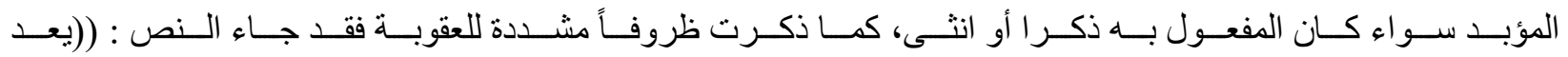

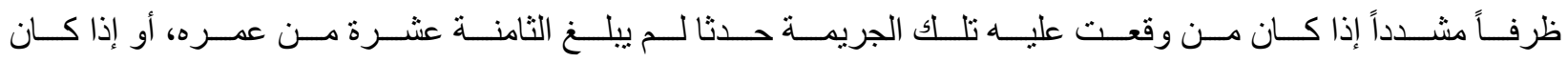

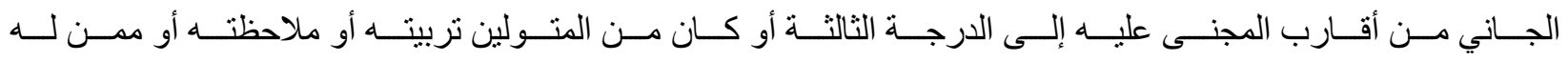

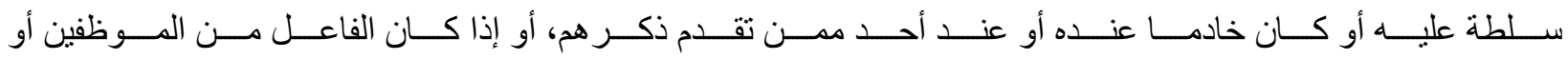

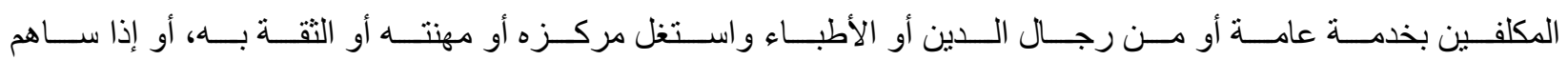

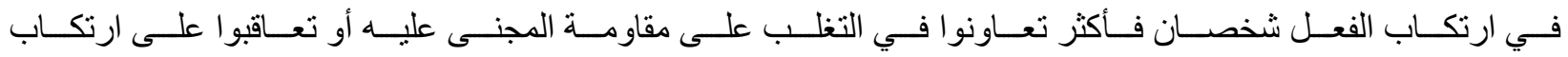

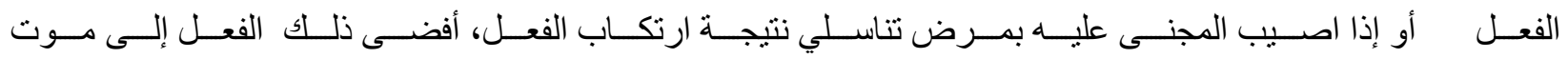
المجنى عليه، إضافة إلى إمكان التعويض تعويضاً مدنياً إذا في بعض الأحوال )).

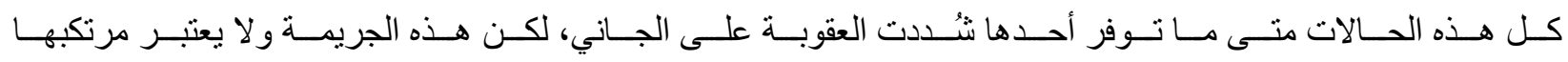

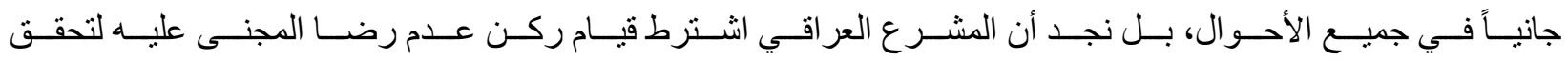




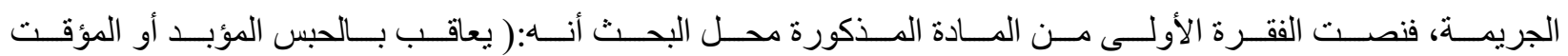
كل من و اقع انتى بغير رضاها أو لاط بذكر أو انثى بغير رضاه أو رضاها) .

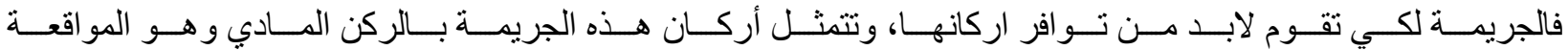
بدون الرضا، و الركن المعنوي و المتمثل بقصد الاعتداء.

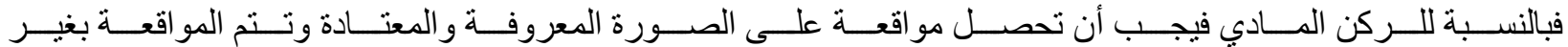
الرضاء أما باستعمال الإكراه المادي أو المعنوي.

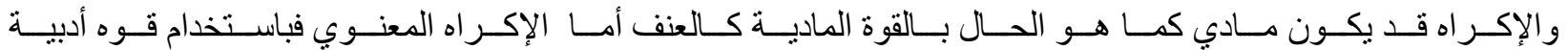

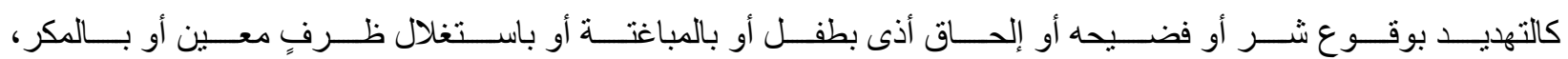

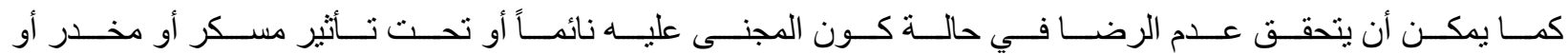

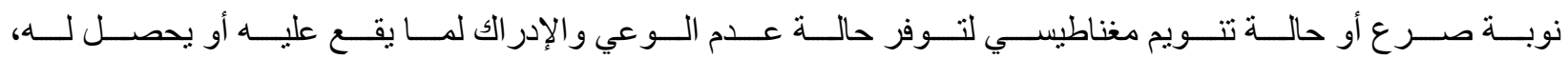

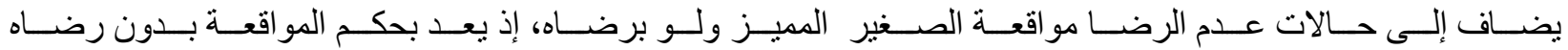

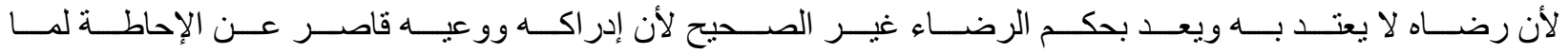

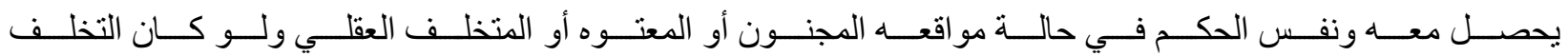
بسيط.

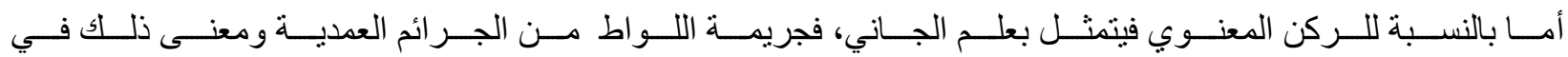

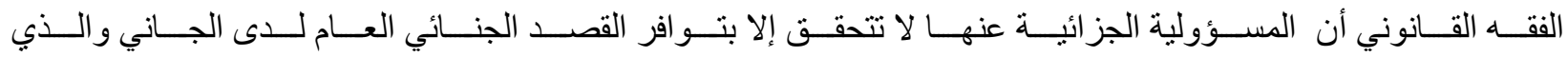

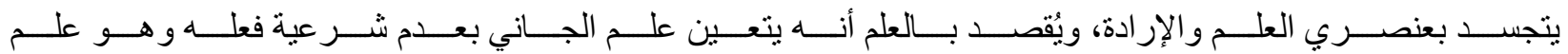

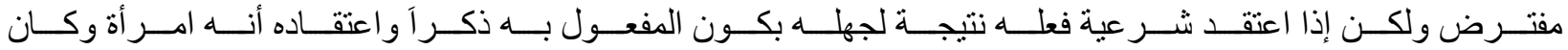

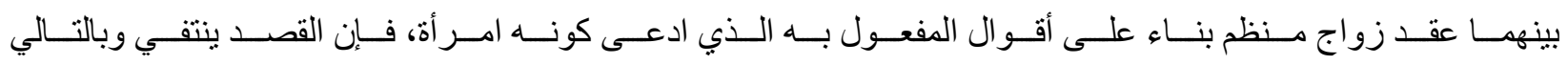
تتنفي المسؤولية الجزائية عن المو اقعة.

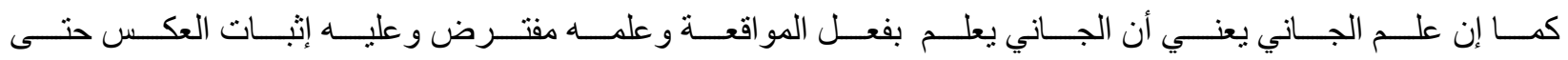

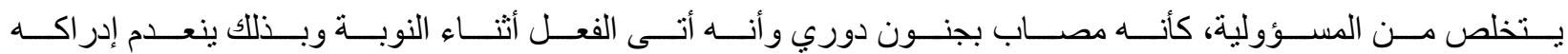
و علمه بما قام به و القصد الجرمي يتوارى بذللك وبالتالي لا مجال لتطبيق حكم المادة 393 عليه. 


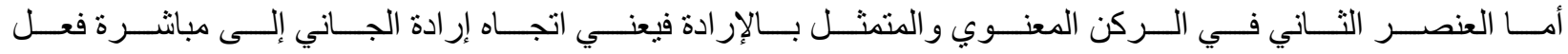

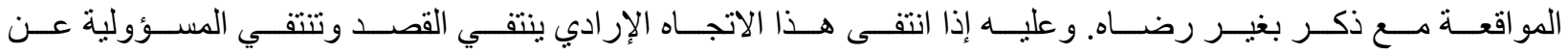

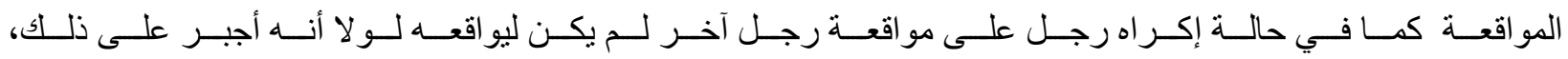

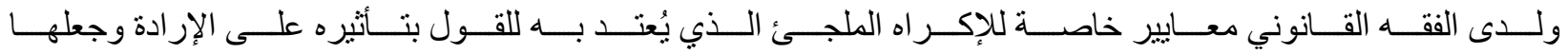

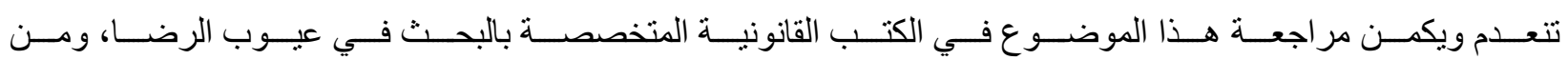

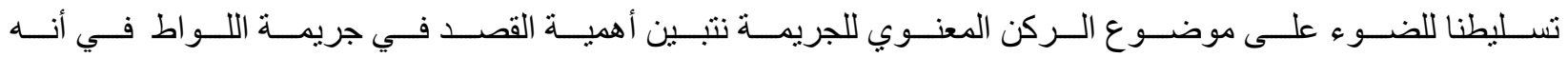
يعد ضابط التفرقة بين الجريمة و عدمها. [33]

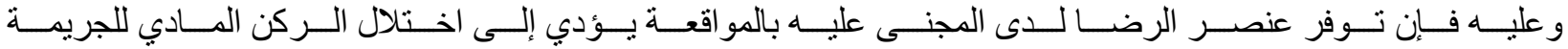

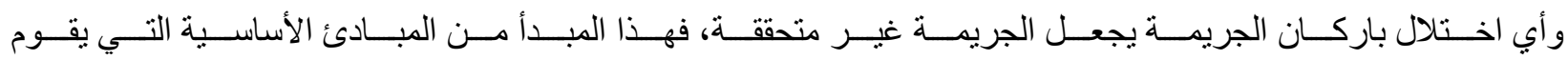

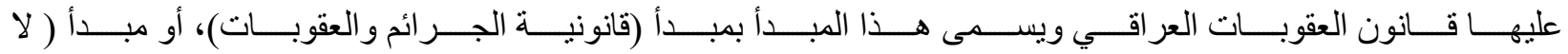

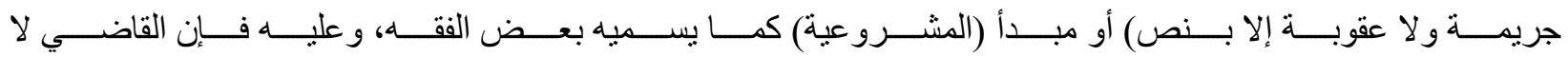

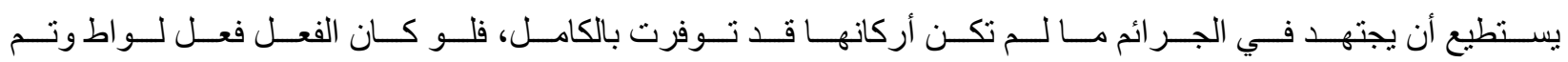

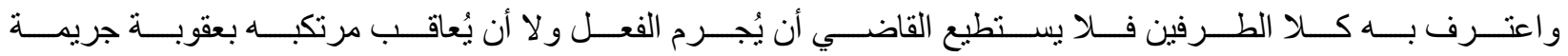

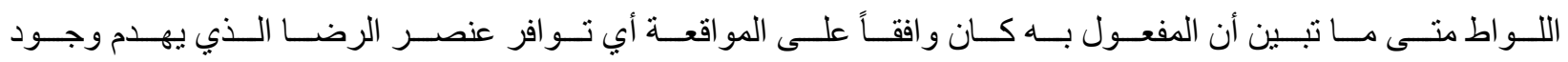

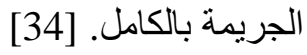

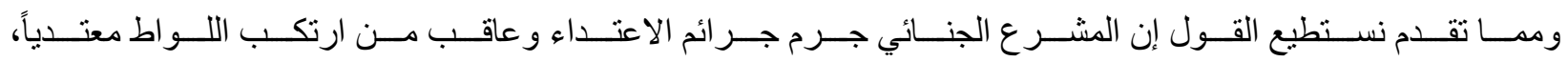

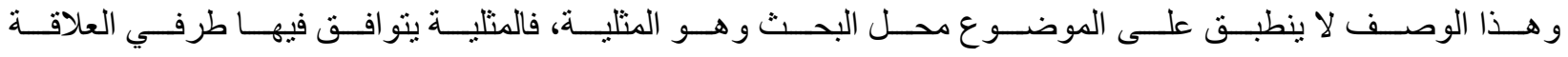

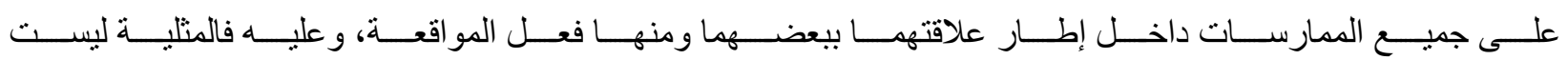
جريمة وفق نص المادة (393) من قانون العقوبات.

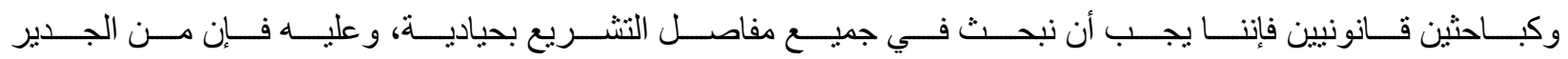

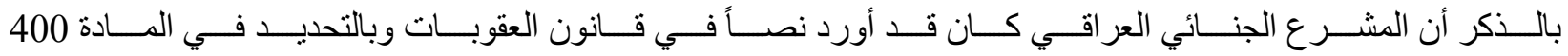

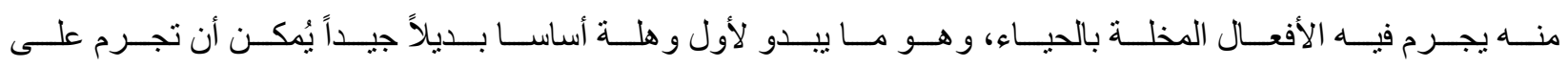

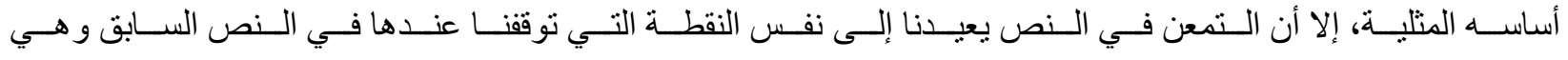

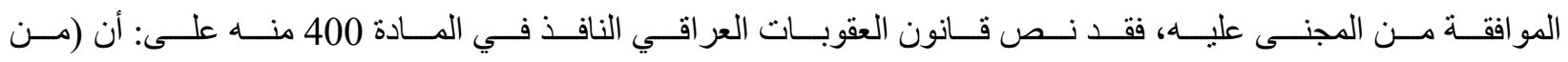




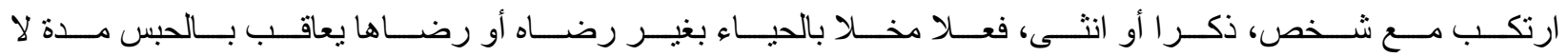

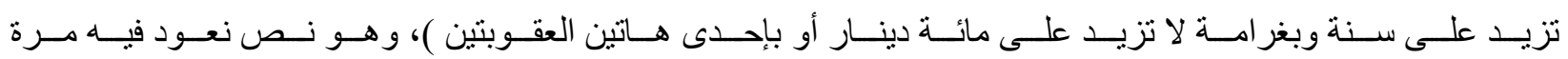

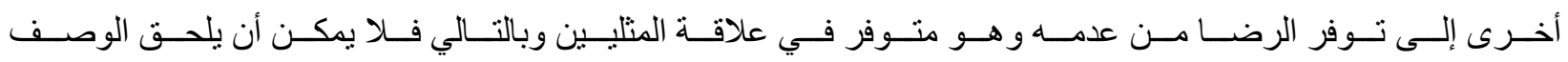
الجرمي بهذا الفعل وفق نص هذه المادة.

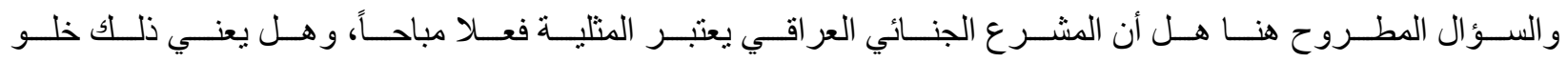
قانون العقوبات العر اقي من إمكان معاقبة (المثليين) ؟

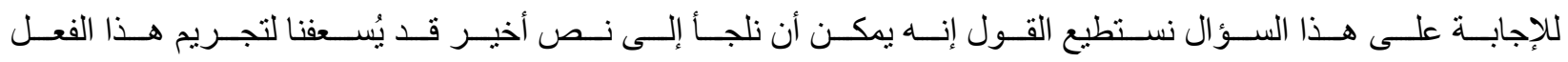

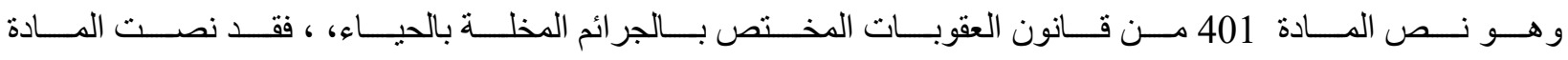

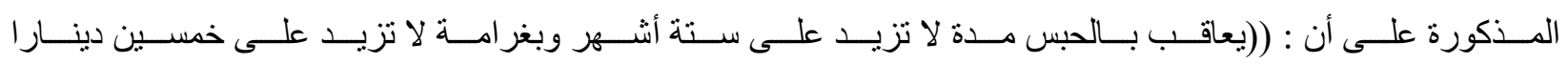
أو بإحدى هاتين العقوبتين من أتى علانية عملا مخلا بالحياء)) .

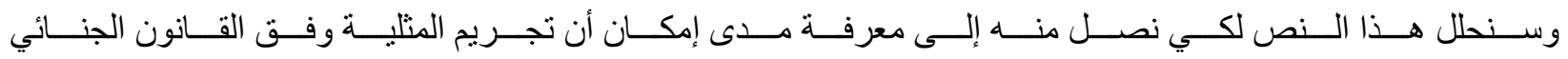
العر اقي أم لا!

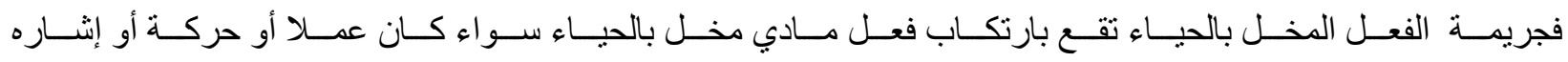

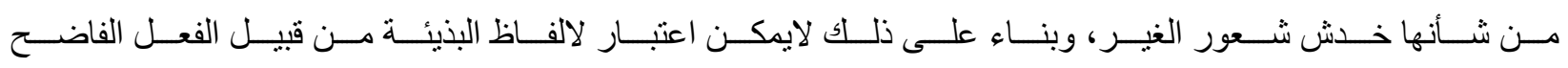

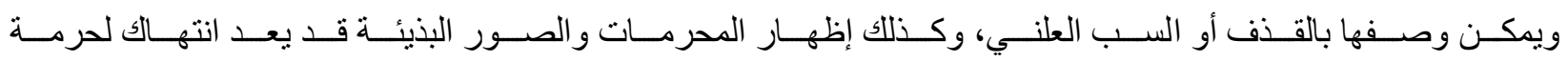

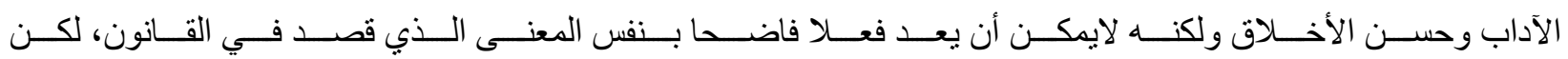

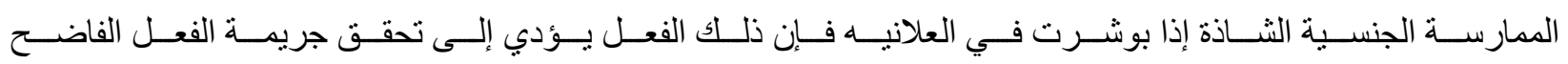

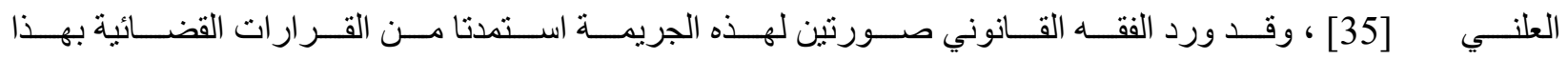

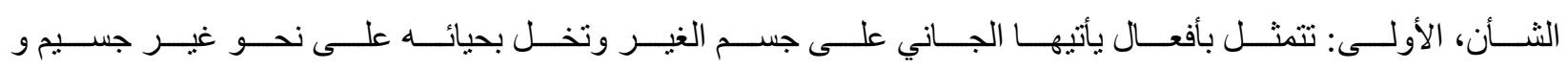

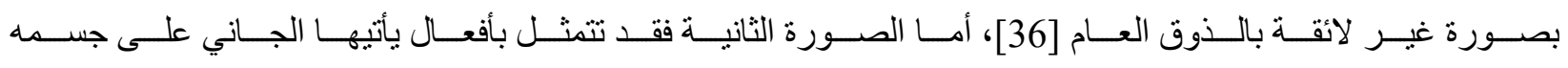

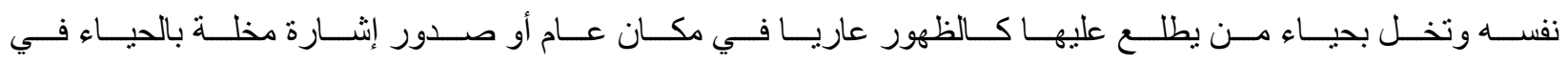

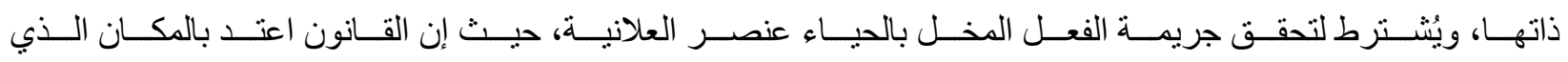
تقع فيه الجريمة واعتبره عنصر لقيام هذه الجريمة. [37] 


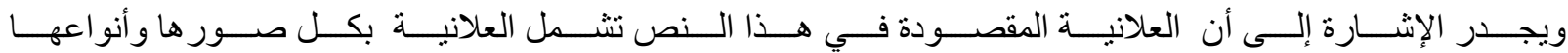

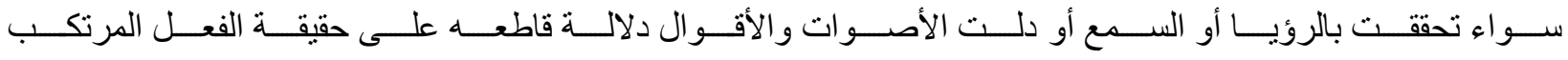

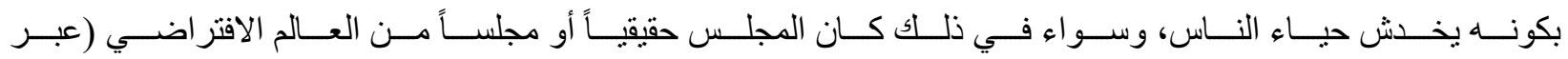

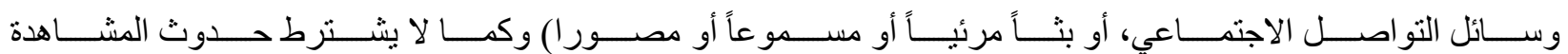

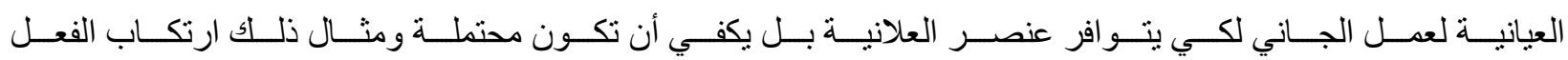

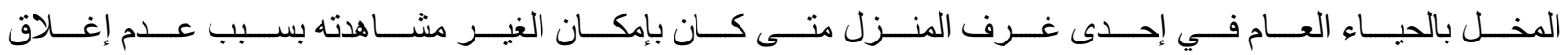

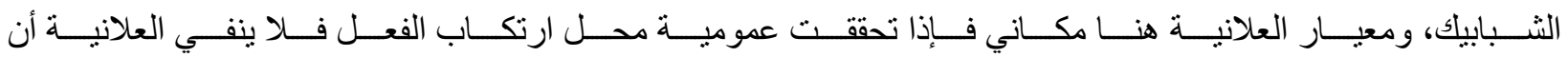

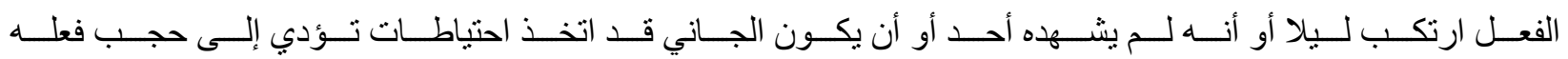
المخل بالحياء عن اطلاع الغير عليها. [38]

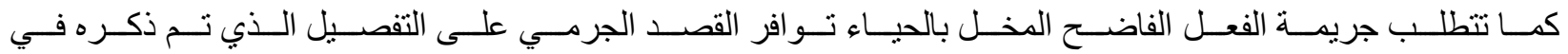
تحليل المادة 393 سابقة الذكر.

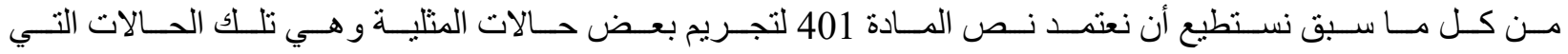

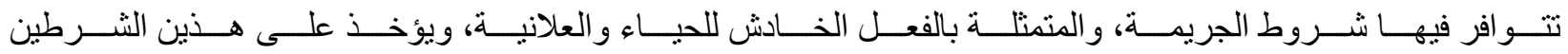

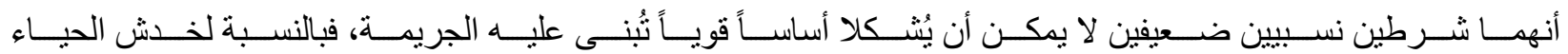

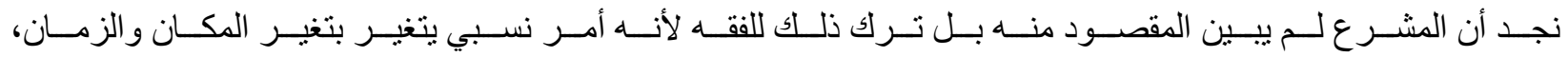

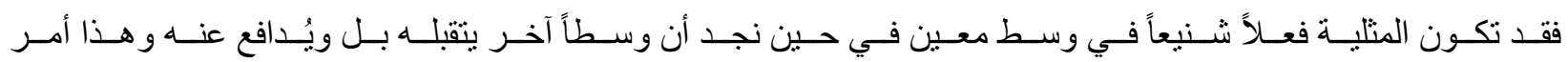

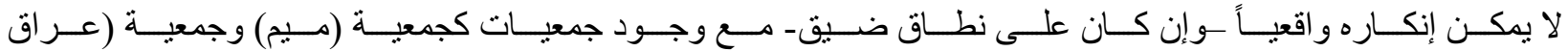

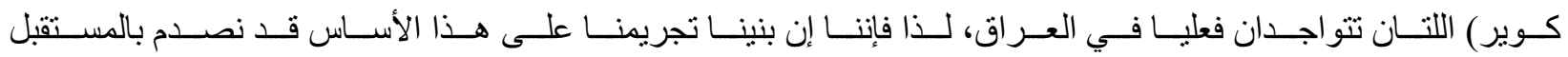

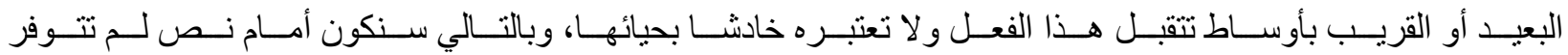

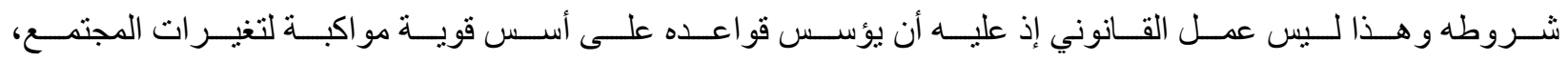

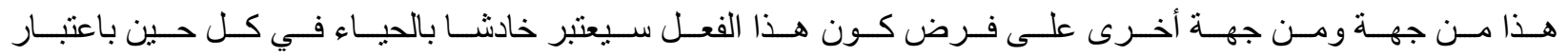

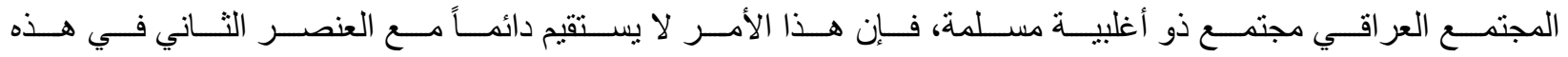

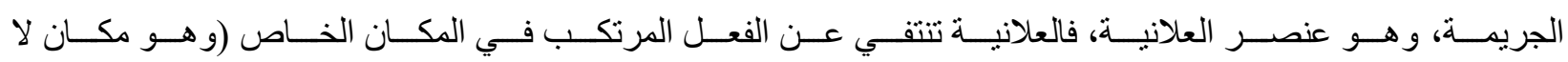

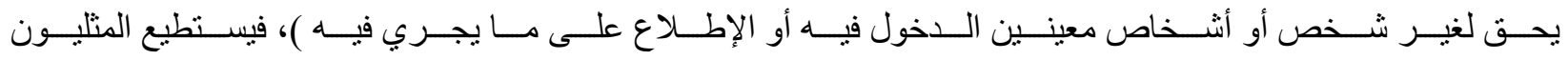




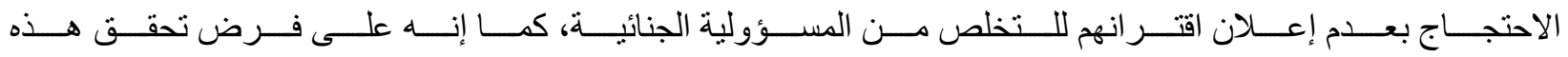

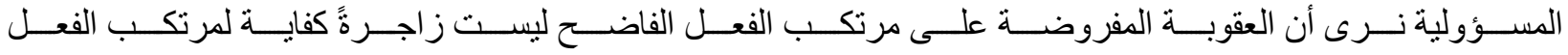

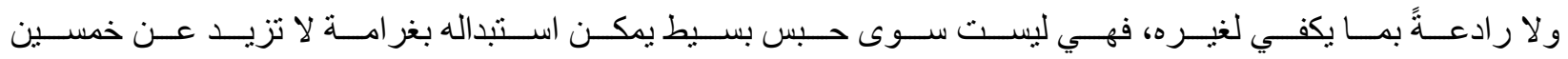
ألف دينار عراقي حسب التعديل، وهذا لا يحقق المأمول.

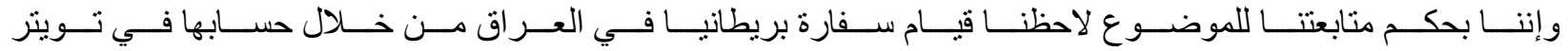

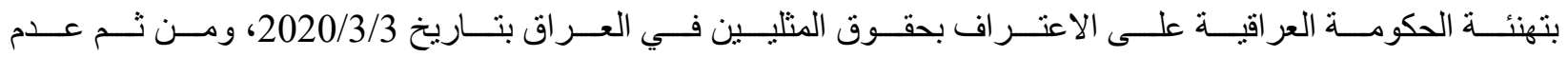
ظهـــور تلــلك (التغريــدة) دون أن يصــدر مــن الحكومـــة العر اقيــة أو الموقــع المــذكور أي تكــذيب أو اعتــذار أو

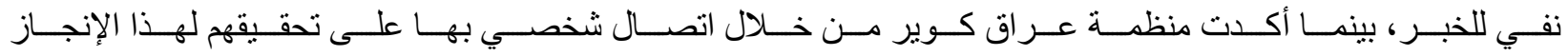

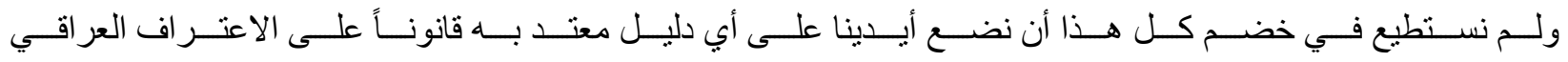
بحقوق الجيل الر ابع للإنسان والتي تعد حقوق المثليين من بينها.

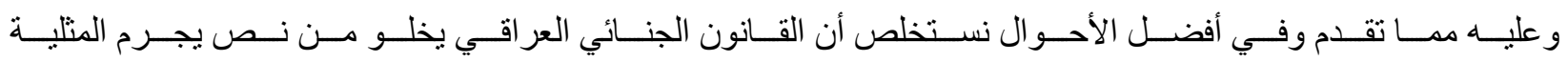

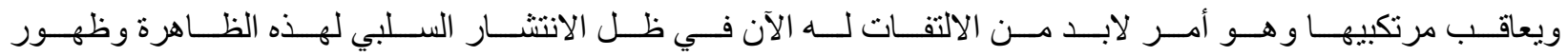

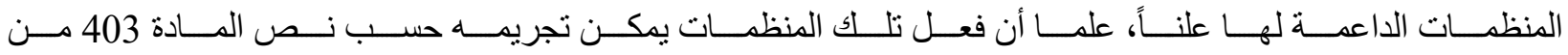

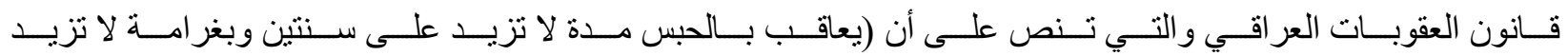

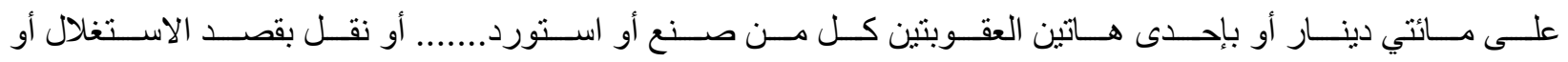
التوزيــع كتابـــا أو مطبو عــات أو كتابــات أخــرى أو رســوما أو صـــور أو افلامـــا أو رمــوزا أو غيــر ذلــك مــن الأشياء إذا كانت مخلة بالحياء أو الآداب العامة.

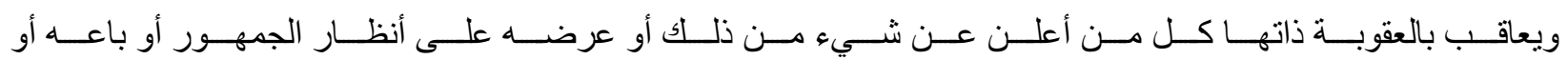

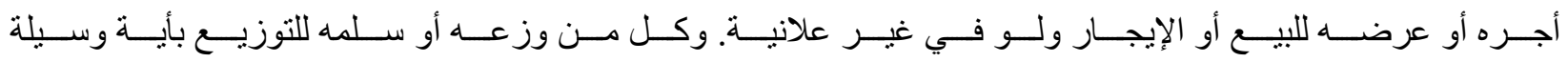
كانت، ويعتبر ظرفا مشددا إذا ارتكبت الجريمة بقصد إفساد الأخلاق)

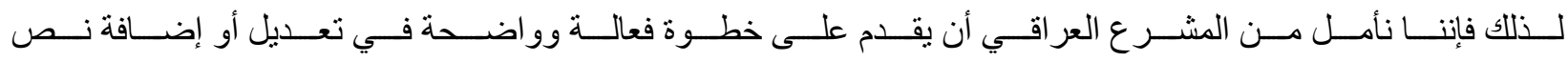

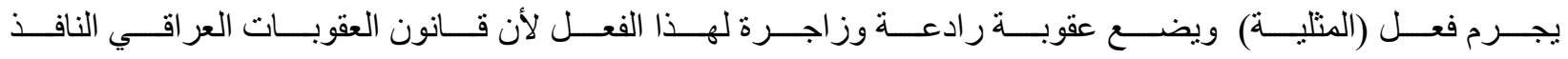




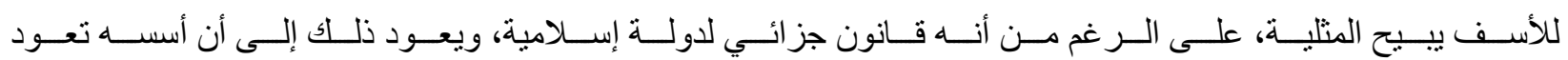
لقانون العقوبات البغدادي الذي وضعته سلطات الانتداب البريطاني في أو ائل القرن السابق.

\section{ثالثا/ موقف بعض التشريعات الجزائية العربية من المثلية}

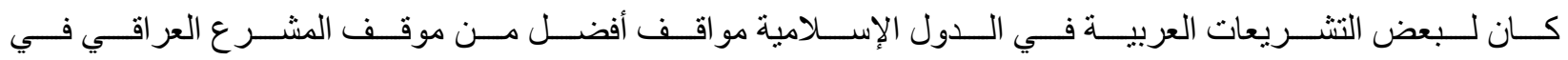

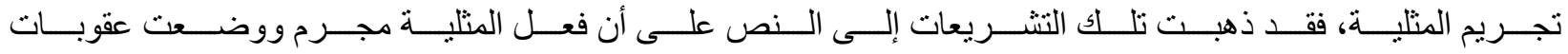

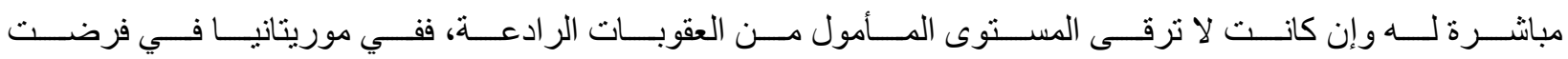
عقوبــة علــى الطــرفين (لا تقــل عـن 3 اشـــهر و لاتزيــد عـن ســنتين وغر امـــة لا تقـل عـن 5000 إلــى 60000 [34] [أوقية موريتانية ).

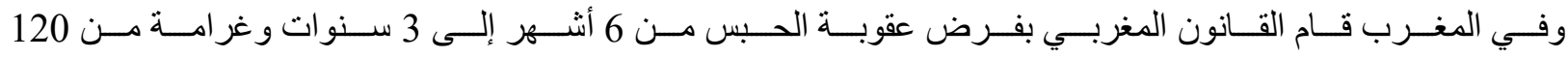

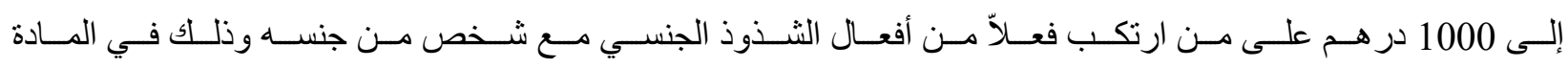
[35] 20189 )

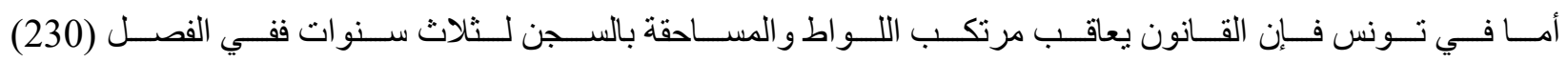

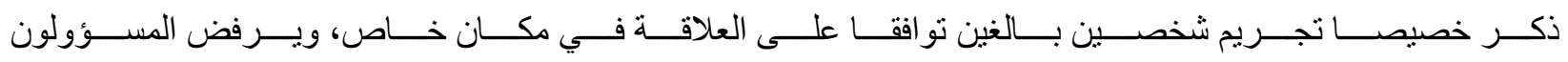
التونسيون النقاش في إجر اء أي تعديل لهذه المادة. [36]

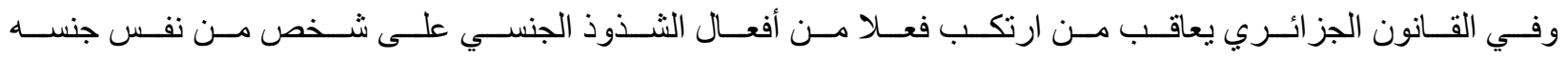

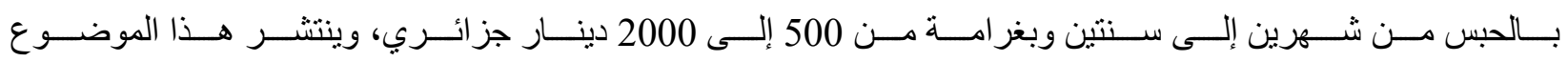

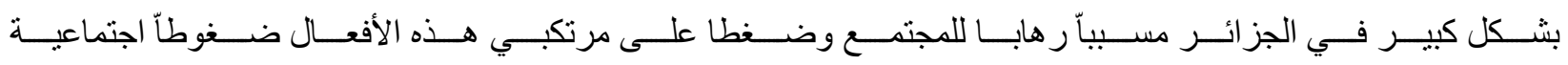
صارمة. [37]

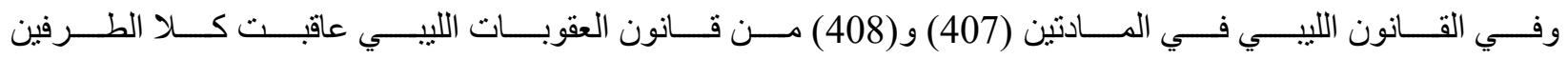

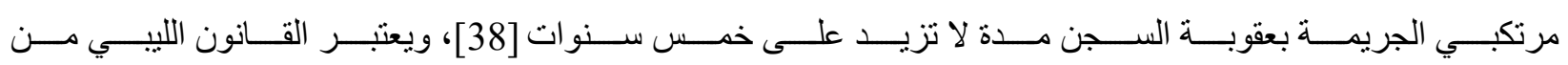

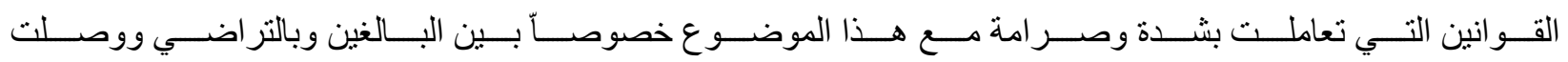

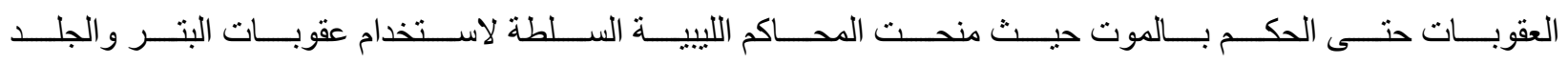




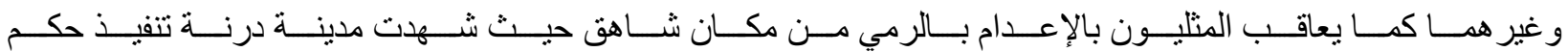
إعدام بحق ثلاثة شبان اتهووا بالمثلية في منتصف العام الماضي .

من خلال البحث في موضوع المتلية توصلنا إلى مجموعة من النتائج و المقترحات أهمها :

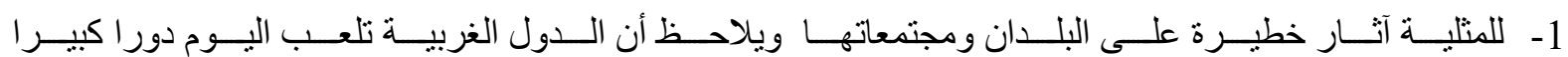
في محاولة نقل هذه الظاهرة لمجتمعاتنا وجعلها مقبولة قانونا.

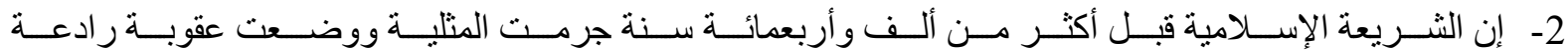
لها تتناسب مع خطورتها في المجتمع بعد أن بينت آثار ها السلبية الجمة على المجتمع.

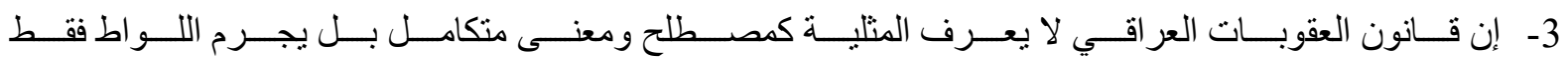
وفي حال كان الفعل تم بدون رضا أحد الطرفين، و هذا ليس مثلية بالمعنى المطلوب.

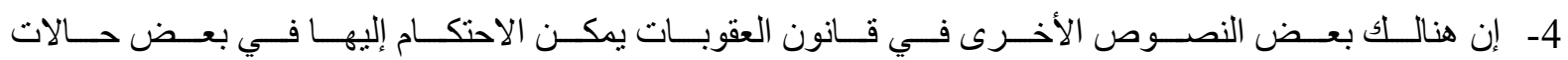
المنلية (كالفعل الفاضح المخل بالحياء) لكنها ليست كافية لحل المشكلة المتفاقمة.

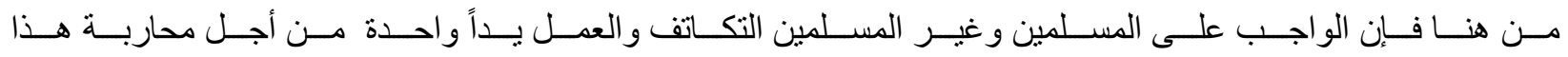
الثذوذ بشتى الوسائل الفردية و الجماعية، ومن هذه الوسائل نقترح:

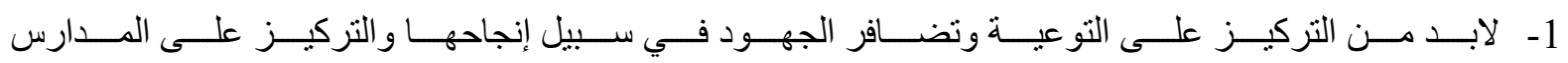
و الجامعات و المؤسسات العقابية.

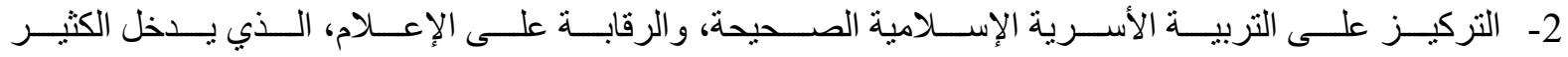

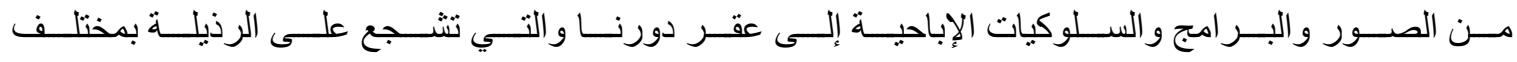
أنو اعها حيث ترسم صورة نمطية خاطئة عن المدنية والتطور تتمثل بالخلاع و الانحر اف.

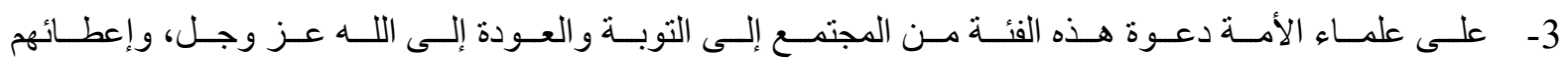
دور هم الكامل ومعاقبة من يحاول تسقيط القدوة التي يمثلونها في المجتمع بالوسائل القانونية.

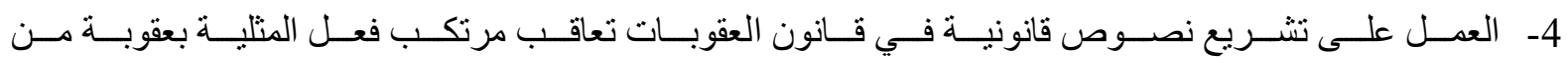

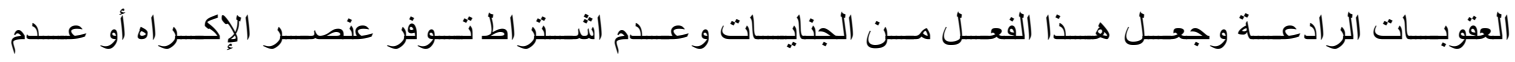




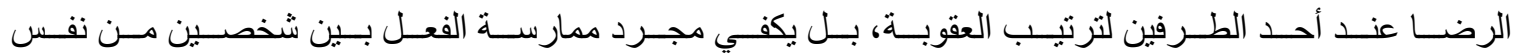

$$
\text { الجنس وثثوت المو اقعة بينهما لترتب العقوبة. }
$$

5- تجريم الفعل وجعله جريمة و إن كانت قد تمت في مكان خاص ولم يتوفر فيها عنصر العلانية.

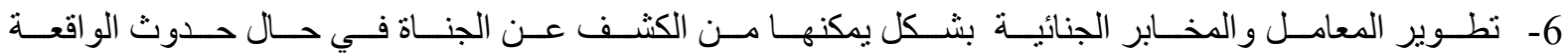

و عدم تحصيل دليل يدين الفاعلين.

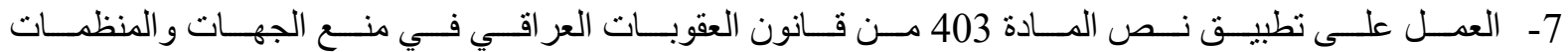

و الأشخاص المروجين لهذه الفكرة و المدافعين عنها علناً.

\section{شكر وتقدير}

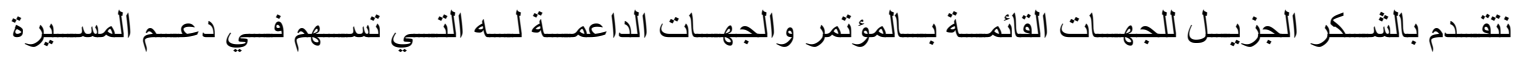

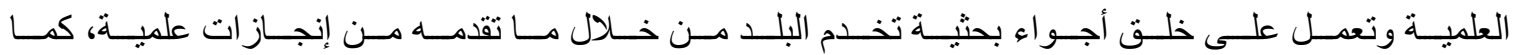

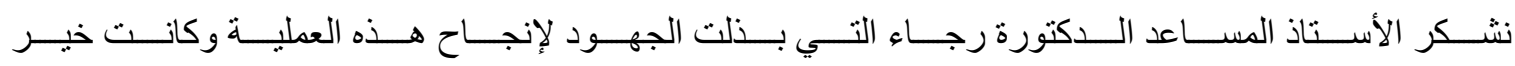

داعمة لنا منذ اليوم الأول الذي تو اصلنا فيه معها بشأن المشاركة والنشر من خلالها.

الباحثات 


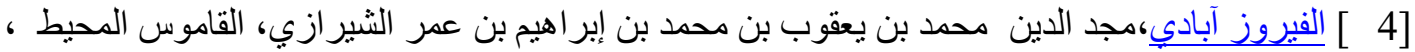

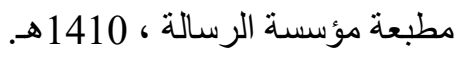

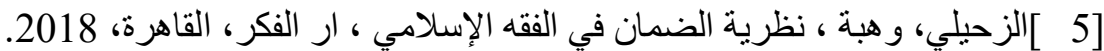

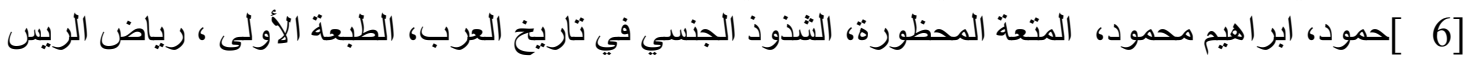
لالنشر، 2000.

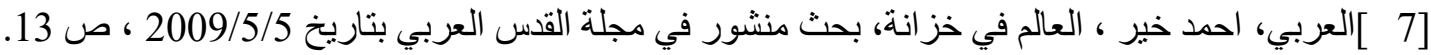

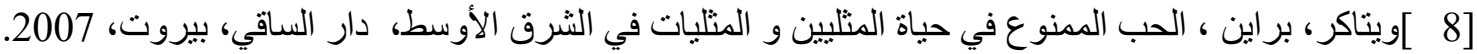

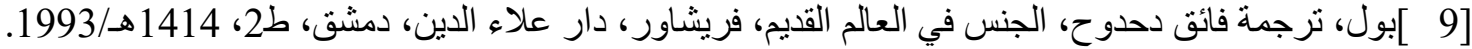

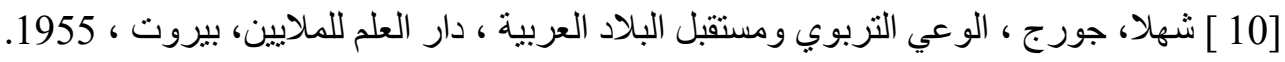

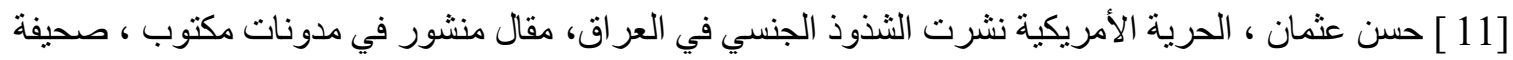

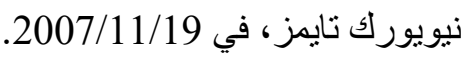

[12 ] الجريسي ، خالد بن عبد الرحمن ، انحر اف الثباب وطرق العلاج على ضوء الكتاب و السنة، مؤسسة

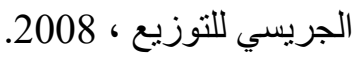

[13 ] انشو ، داج أو ستين ، الجنس و الدين (التعاليم والمحظورات في عالم الاديان) ، ترجمة مرضي زنباع، دار

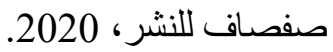

[14 ] السامر ائي، عدلي وآمال عبد الحميد وطلعت لطفي ،علم اجتماع الجريمة و الإنحر اف ، دار المسبرة، عمان ، 2010

[15 ] لاغر انج، فريدريك ،النز عات والحياة الجنسية ودراسات الهويات الجنسية اللانمطية ، مقال منشور في مجلة

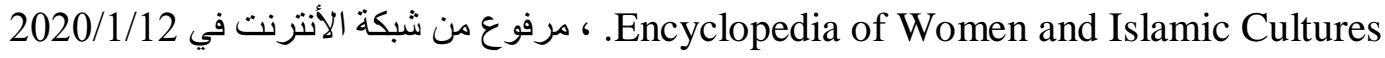

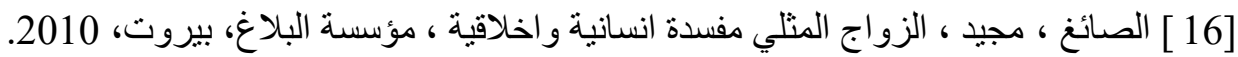

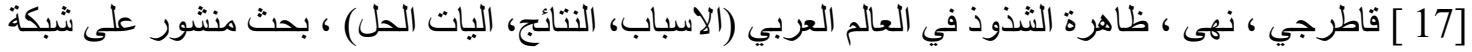

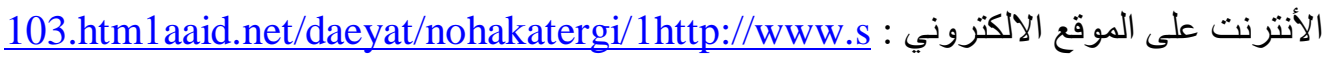

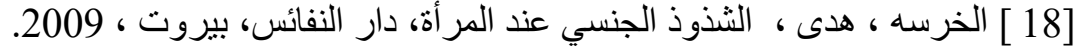

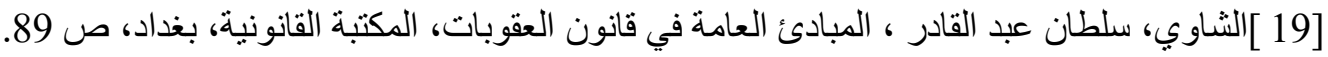

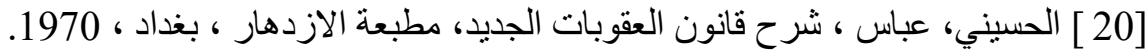
[21 ] رشيد، علي صالح رشيد ، كتاب الحماية الجنائية للحياة الخاصة للإنسان، اكاديمية الإنية نايف العربية للعلوم،

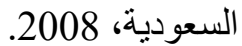

[22 [ الثاذلي، فتوح عبد الله ، قانون العقوبات ـ القسم العام ـ ك1 اوليات القانون الجنائي ـ النظرية العامة

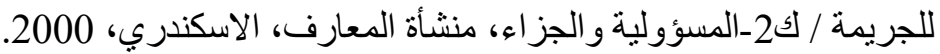
[23 ] الحديثي، فخري عبد الرزاق صلبي ، شرح قانون العقوبات، القسم الخاص، العاتلك لصناعة الصناعة الكتاب، 2009.

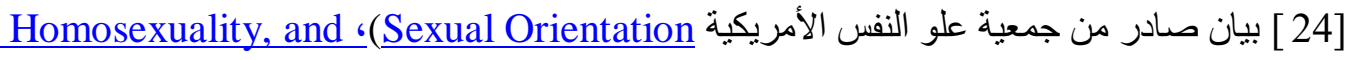

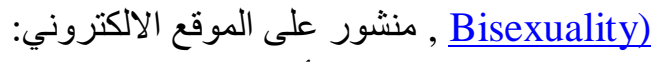

[25] بيان صادر من جمعية الأطباء النفسيين ، البيانات التي نشرنها جمعية على موقعها الرسمي على شبكة

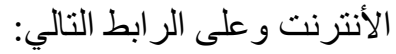

[26] بيان صادر من جمعية علو النفس الأمريكية ( Sexual Orientation, Homosexuality, and

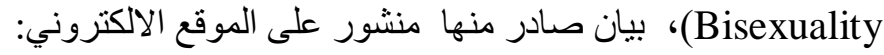
[27 ] بيان لمنظمة ( Human right watch) منشور على موقعها الرسمي على شبكة الأنترنت وعلى الموقع

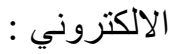




$$
\text { [28 ] بيان المفوضية السامية للامم المتحدة، منشور لها على موقعها الاليكتروني الرسمي. }
$$

[29] Bleysc, C., The geography of perversion. Male-to-male sexual bbehaviour outside the West and the ethnographic imagination, 1995.

[30 ]tewart, Chuck (Volume I, 2010). The Greenwoods Encyclopedia of Lgbt Issues Worldwide. ABC-CLIO.

[31 ]Wellingss, K.\& Field, J.\& Johnsons, A.\& Wadsworths ,Sexual behaviors in Britain: The national survey of sexual attitudess and lifestyles. Penguins Books, , J.1994.

$$
\text { [32] جورج شهلا، المصدر السابق، ص 33. }
$$

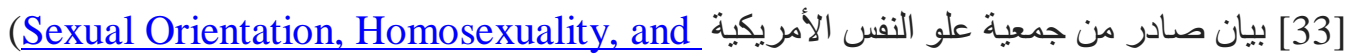

$$
\text { Bisexuality), }
$$

https://web.archive.org/web/20200208114543/http://www.apa.org/helpcenter/sexual2020/2/7 و و orientation.aspx

$$
\begin{aligned}
& \text { [34] الجريسي، خالد بن عبد الرحمن ، المصدر السابق، ص } 39 . \\
& \text { [35] ويتاكر ،براين ، الحب الممنوع، حياة المثليين والمتنليات في الثرق الأوسط، ترجمة ف. ابراهيم، دار الساقي، }
\end{aligned}
$$

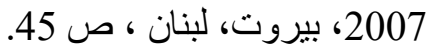

$$
\begin{aligned}
& \text { [36] بول، ترجمة فائق دحدوح، الجنس في العالم القيم، فريشاور، دمشق، دار علاء الدين، ط2، 1414هـ/1993م، }
\end{aligned}
$$

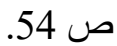

$$
\begin{aligned}
& \text { [37] محمو د، ابر اهيم ، المنعة المحظورة، الثذوذ الجنسي في تاريخ العرب، رياض الريس للكتب و النشر ، الطبعة }
\end{aligned}
$$

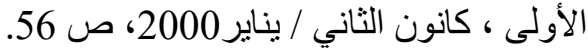

